\title{
Sport jako alternatywne narzędzie dyplomacji na przykładzie relacji amerykańsko-irańskich po 1979 roku
}

\begin{abstract}
Abstrakt: Sport nierzadko bywa wykorzystywany jako nieoficjalne narzędzie dyplomacji i/lub aktywizacji obywatelskiej - zwłaszcza w zwyczajowo napiętych relacjach między demokracjami a reżimami autorytarnymi, jak miało to miejsce w omawianym przypadku USA i Islamskiej Republiki Iranu. W artykule zasadnicze miejsce zajmuje analiza tego, w jaki sposób pod koniec lat dziewięćdziesiątych zapasy i piłka nożna - dyscypliny popularne w obu państwach - umożliwiły wyjście z obopólnej izolacji trwającej nieprzerwanie od 1979 r.
\end{abstract}

Słow a kluczowe: sport, społeczeństwo obywatelskie, stosunki amerykańsko-irańskie, dia$\log$ cywilizacji.

Abstract: Sport is oftentimes used as an unofficial instrument of diplomacy and/or civic activism - especially in usually tense relations between democracies and authoritarian regimes - as was the case concerning the USA and the Islamic Republic of Iran. The main focus of this article is to analyze the way in which wrestling and football - sport disciplines that are popular in both these countries - made it possible to get out of mutual isolation lasting uninterruptedly since 1979 .

Key w ord s: sports, civil society, US-Iranian relations, dialogue among civilizations.

\section{Wprowadzenie}

W niniejszym artykule na przykładzie relacji amerykańsko-irańskich sformułowano tezę, iż sport bywa wykorzystywany jako alternatywne narzędzie dyplomacji. Sytuacja ta często występuje w kontaktach między państwami demokratycznymi (tu: Stany Zjednoczone) a reżimami autorytarnymi (za jaki uznaje się współczesny Iran), zwłaszcza gdy oficjalne relacje są niemożliwe 
lub mocno utrudnione. Dzieje się tak w przypadku USA i Iranu po 1979 r. W wyniku antyimperialistycznej i nastawionej antyzachodnio rewolucji islamskiej z lat 1978-1979 Iran dynastii Pahlawi (1925-1979) - niedawny sojusznik Ameryki; państwo, którego system polityczny trudno nazwać demokratycznym $^{1}$ - przeistoczył się w Islamską Republikę Iranu, której nowe, teokratyczne władze z antyamerykanizmu uczyniły swój dogmat polityczny. Relacje te uległy zawieszeniu (nieodwołanemu do dzisiaj) po ataku na amerykańską ambasadę w Teheranie 4 XI 1979 r. i przejęciu jako zakładników pracowników tejże ambasady na okres 444 dni (do 20 I 1981)2. W połowie lat dziewięćdziesiątych, w momencie próby liberalizacji irańskiego ustroju teokratycznego za prezydentury Mohammada Chatamiego (1997-2005), gdy Iran częściowo otworzył się na Zachód, odtworzono część relacji - zwłaszcza w dziedzinie kultury i sportu - pełniejszą integrację sabotował jednak ajatollah Ali Chamenei ${ }^{3}$. W kontekście sportu przełomowe znaczenie miały dwa wydarzenia z 1998 r.: gościnny udział amerykańskich zapaśników na zawodach Takhi Cup rozgrywanych w lutym w Teheranie (rozpoczynający tzw. dyplomację zapaśnicza) oraz mecz Iran-USA 21 czerwca na piłkarskich mistrzostwach świata we Francji (najważniejszy akt „dyplomacji futbolowej”). Poniżej przedstawiam ich możliwie szczegółowy opis.

${ }^{1}$ O Iranie w okresie rządów dynastii Pahlawi por. m.in.: Th. Coville, Najnowsza historia Iranu. Republika islamska, tłum. K. Pachniak, Warszawa 2009, s. 19-39; E. Abrahamian, Historia wspótczesnego Iranu, Warszawa 2011, s. 101-2003; M. Stolarczyk, Iran. Państwo i religia, Warszawa 2001, s. 28-65; H. Nahavandi, Upadek i śmierć szacha Iranu. Relacje $i$ dokumenty, tłum. Z. Józefowicz-Niedźwiecka, Warszawa 2008; J. Kalabiński, Iran - nowe mocarstwo?, Warszawa 1977; R. Kapuściński, Szachinszach, Warszawa 2008.

${ }^{2}$ Wydarzenia w Iranie miały wpływ na sytuację wewnętrzną w Stanach Zjednoczonych. Nieudana próba odbicia zakładników, opatrzona kryptonimem „Eagle Claw”, w trakcie której zginęło 9 osób (8 marines i 1 irański cywil), uznawana jest za jedna z przyczyn porażki starającego się o reelekcję Jimmy'ego Cartera w amerykańskich wyborach prezydenckich z 1980 r. Por. m.in.: Z. Brzeziński, Cztery lata w Biatym Domu. Wspomnienia Doradcy do Spraw Bezpieczeństwa Państwa 1977-1981, tłum. Z. Dziekoński, Warszawa 1989, s. 339-380.

${ }^{3} \mathrm{~W}$ systemie politycznym Islamskiej Republiki Iranu obowiązuje zasada velāyat-e faqīh (,zwierzchności uczonego prawnika”), którego rolę pełni najwyższy przywódca, zwany też rahbarem. Konstytucja z 1980 r. ustanowiła nadrzędność władzy faqīha nad prezydentem. Do kompetencji faqīha należy m.in. nadzór nad realizacją głównych założeń ustrojowych, zwierzchnictwo nad siłami zbrojnymi i prawo do wypowiadania wojny, powoływanie i odwoływanie urzędników państwowych, ustalanie i nadzorowanie kryteriów, jakie muszą spełniać kandydaci na prezydentów i parlamentarzystów. Por. M. Stolarczyk, op. cit., s. 298-299. $\mathrm{W}$ istocie faqīh jest przywódca w sensie politycznym i religijnym, zaś prezydent jedynie zarządca państwa. Co paradoksalne: Chatami jest duchownym, posiada wysoki tytuł hojatoleslām, zalicza się do grona bezpośrednich potomków Proroka (czego świadectwem jest noszony przez niego czarny turban), zaś Chamenei posiada najwyższy tytuł ajatollaha, otrzymał go jednak honorowo po śmierci ajatollaha Ruhollaha Chomejniego (1989), wcześniej należał do kleru klasy średniej. Chomejni wybrał Chameneiego na swojego następcę, gdyż uznał go za „dobrego administratora”, którego Iran - osłabiony po wyniszczającej wojnie iracko-irańskiej (1980-1988) - najbardziej potrzebuje. Por. Th. Coville, op. cit., s. 68-75. 
W kontekście omawianego przeze mnie tematu sport pełnił trzy zasadnicze funkcje: 1) jako pretekst dla odbudowy wzajemnego porozumienia między Stanami Zjednoczonymi a Islamską Republiką Iranu'; 2) narzędzie umożliwiające uchwycenie nastrojów społecznych (wobec braku dyplomatów i odpowiedniej infrastruktury); 3) miejsce, gdzie możliwy jest rozwój społeczeństwa obywatelskiego i najłatwiej wyrazić protest względem polityki władz (wspierający wolnościowe dążenia Irańczyków Amerykanie powinni mieć to na uwadze). Pierwszą funkcję starano się realizować $\mathrm{w}$ duchu zbliżonym do dyplomacji tradycyjnej (tzw. klubowej) i/lub dyplomacji sieciowej, pozostałe dwie wiążą się bardziej z dyplomacją publiczna. W celu dalszej klarowności wywodu konieczne jest zatem wytłumaczenie tych pojęć i przedstawienie ich znaczenia. Istotne miejsce zajmuje też ukazanie „dialogu cywilizacji” - politycznej idei prezydenta Chatamiego jako platformy wzajemnego kontaktu, z której najefektywniej skorzystali sportowcy, działacze sportowi, członkowie organizacji pozarządowych - oraz charakterystyka stadionu (i innych obiektów) jako specyficznego miejsca w społecznym krajobrazie Islamskiej Republiki Iranu.

\section{Sport - dyplomacja - polityka}

Jak zauważają David Black i Byron Peackock, „sport i dyplomacja posiadaja długa, często nieprzewidywalną i generalnie niedocenianą relację, przynajmniej od czasu powstania nowoczesnego ruchu olimpijskiego pod koniec XIX w." Biorąc pod uwagę widowiskowość, popularność i potencjał mobilizacyjny współczesnego sportu nie powinien szczególnie zaskakiwać fakt, iż drużyny sportowe, wydarzenia i areny nierzadko służą celom pozasportowym. Lincoln Allison, na którego powołują się Black i Peackock, stworzył pojęcie „mit autonomii sportu", akcentując pozorną apolityczność sportu. Zauważył, że pomimo iż sport i polityka nieustannie ze sobą koliduja, znacząca część widzów skłonna jest utrzymywać, iż te dziedziny są od siebie niezależne ${ }^{6}$. Sport bywał i bywa wykorzystywany w roli tuby propagandowej, zwłaszcza przez władze niedemokratyczne, które posługuja się nim celem ugruntowania swojej władzy i zdobycia międzynarodowego uznania ${ }^{7}$. Stanowi zatem użyteczne narzędzie

\footnotetext{
${ }^{4}$ Zabiegi te podejmowane były na drodze oficjalnej i nieoficjalnej. Częściej zachodził ten drugi przypadek.

${ }^{5}$ D. Black, B. Peackock, Sport and Diplomacy, w: The Oxford Handbook of Modern Diplomacy, ed. A.E. Cooper, J. Heine, R. Thakur, Oxford 2013, s. 708 [tłumaczenie własne; odnosi się to również do kolejnych tytułów anglojęzycznych].

${ }^{6}$ Por. ibidem; L. Allison, The Changing Concept of Sporting Life, w: The Changing Politics of Sport, ed. L. Allison, Manchester-New York 1993, s. 5-6.

7 Znane przykłady takiego wykorzystania sportu to organizacja letnich igrzysk olimpijskich w Berlinie (1936), Moskwie (1980) i Pekinie (2008). Zwycięstwa włoskich piłkarzy na
} 
zarówno w polityce wewnętrznej, jak i zagranicznej. Postępowanie to nie było obce władzom w przedrewolucyjnym Iranie ${ }^{8}$. Należy przy tym pamiętać, iż nie jest to właściwość wyłącznie reżimów autorytarnych bądź totalitarnych. Sport powyższą funkcję spełniał również w Stanach Zjednoczonych ${ }^{9}$. Niekoniecznie musi on służyć wyłącznie jako instrument umacniania nacjonalizmu bądź legitymizacji władz pozbawionych demokratycznego uprawomocnienia. Jego funkcja bywa odwrotna, np. pogłębianie procesów demokratyzacyjnych ${ }^{10}$.

Polityczna rolę sportu Black i Peackock analizuja w kontekście tzw. dyplomacji tradycyjnej - klubowej (club diplomacy) i dyplomacji sieciowej (network diplomacy). W pierwszej fundamentalną rolę odgrywają organy władzy państwowej - szefowie i członkowie rządów, parlamentarzyści, głowy państw. Dyplomacja klubowa dominowała w ciagu ostatnich stuleci. Jej rola uległa ostatnio zmniejszeniu, aczkolwiek wciąż pozostaje istotna, z racji priorytetowej ważności interesów narodowych, które stara się reprezentować.

mundialach we Włoszech (1934) i Francji (1938) Benito Mussolini starał się wykorzystać celem wzmocnienia nacjonalizmu oraz dumy z państwa faszystowskiego. Analogiczne próby podejmowała junta generałów podczas piłkarskich mistrzostw świata w Argentynie (1978), w których tryumfowali gospodarze.

8 W kontekście Iranu takim narzędziem okazała się organizacja siódmych igrzysk azjatyckich w Teheranie w 1974 r. Por. m.in.: A.M. Amirtash, Iran and the Asian Games. The Largest Sports Event in the Middle East, w: Sport, Nationalism and Orientalism, ed. F. Hong, London-New York 2013, s. 46-63; H.E. Chehabi, The Juggernaut of Globalization. Sport and Modernization in Iran, w: Sport in Asian Society. Past and Present, ed. J.A. Mangan, F. Hong, London 2003, s. 225-239.

${ }^{9}$ Letnie igrzyska olimpijskie w Los Angeles (1984) stały się pretekstem do zademonstrowania dumy z bycia Amerykaninem - uczucia, które po traumatycznych doświadczeniach wojny wietnamskiej i trudnych latach siedemdziesiątych (détente ze ZSRR, kryzys naftowy, Watergate, rewolucje proletariackie w Azji i Ameryce Południowej, rewolucja islamska w Iranie) „odzyskała” ekipa Ronalda Reagana. Wydarzenie to wpisywało się zatem w specyfikę „rewolucji konserwatywnej” z lat osiemdziesiątych. Zdaniem Maynarda Brichforda olimpiada w Los Angeles „stanowiła przełom zarówno, gdy idzie o amerykański nacjonalizm, jak i komercjalizację igrzysk”. Były to bowiem pierwsze igrzyska, których niemal cały budżet sfinansowali prywatni inwestorzy. Por. M. Brichford, Avery Brundage and American Nationalism at the Olympic Games, w: The Global Nexus Engaged. Past, Present, Future Interdisciplinary Olympic Studies, ed. K.B. Wamsley, R.K. Barney, S.G. Martyn, London-Ontario 2002, s. 225, http://library.la84.org/SportsLibrary/ISOR/ISOR2002zc.pdf (dostęp: 31 X 2014).

${ }^{10}$ Przyznanie RFN prawa do organizacji XX Letnich Igrzysk Olimpijskich w Monachium (1972) można zatem interpretować jako akt uznania dla dynamiki i skuteczności zmian zachodzących w Niemczech Zachodnich po 1945 r. Podobna motywacja stała za wcześniejszymi decyzjami o przyznaniu olimpiady Rzymowi (1960) i Tokio (1964). Międzynarodowa społeczność olimpijska skutecznie izolowała Republikę Południowej Afryki za politykę apartheidu. Przez długi czas (do 1984 r.) miejsce komunistycznych Chin zajmowała tajwańska Republika Chińska. W reakcji na sowiecką inwazję na Afganistan w 1979 r. USA zbojkotowały udział na olimpiadzie w Moskwie (1980) - reprezentacje krajów bloku komunistycznego (z wyjątkiem Rumunii Nicolae Ceauşescu) nie pojechały do Los Angeles. Por. D. Black, R. Peackock, op. cit., s. 711-714. 
Klasycznym przykładem jest dziewiętnastowieczny koncert mocarstw ${ }^{11}$. Jorge Heine, doświadczony dyplomata, opisuje to następujaco:

W „klubowym” modelu dyplomacji dyplomaci spotykają się wyłącznie z urzędnikami rządowymi, ludźmi takimi jak oni sami, czasem okazyjnie spotyka się z biznesmenem albo bizneswoman, udzieli wywiadu, wygłosi przemowę tam czy tu. Ogólnie mówiąc ograniczają się do znajomych członków klubu, w towarzystwie których czują się najbardziej komfortowo i skupiają swoje umysły na „prowadzeniu negocjacji między niepodległymi państwami” ${ }^{2}$.

Charakter dyplomacji sieciowej jest bardziej złożony, przez co lepiej odpowiada on obecnym czasom. Angażuje bowiem szereg podmiotów poza bądź ponadpaństwowych o zasięgu lokalnym, regionalnym lub (najczęściej) międzynarodowym. Heine stwierdza, iż:

w świecie XXI w. „klubowy model” dyplomacji ustapił miejsca [...] mniej hierarchicznemu modelowi sieciowemu, w którym dyplomaci stykają się ze znacznie większa liczbą ludzi w kraju goszczącym - wliczając w to osoby, które nawet nie pomyślałyby, aby postawić swą stopę w salonach i prywatnych klubach $\mathrm{z}$ ich rozrzedzona atmosfera, gdzie zwykli uczęszczać dyplomaci z niedawnych lat. Dyplomacja coraz bardziej polega na „zarządzaniu złożonością” w stopniu, jakiego wcześniejsi mistrzowie, jak Richelieu, nawet nie byli w stanie sobie wyobrazićc ${ }^{13}$.

Z dyplomacją sieciową związana jest działalność międzynarodowych organizacji sportowych (International Sport Organizations - ISOs) ${ }^{14}$, międzyrządowych organizacji (Intergovernmental Organizations - IGOs $)^{15}$ czy wielonarodowych korporacji (Multinational Organizations - MNOs) ${ }^{16}$. Członkostwo w organizacjach, takich jak Międzynarodowy Komitet Olimpijski (MKOl) czy Fédération Internationale de Football Association (Międzynarodowa Federacja Piłki Nożnej; FIFA), oraz możliwość uczestniczenia w wydarzeniach dziejacych się pod ich auspicjami wymaga spełnienia wielu, często drobiazgowych, wymagań formalnych, jak również podzielania głoszonych przez nie wartości

${ }^{11}$ Dość często pojawiają się opinie, że współczesna sytuacja międzynarodowa przypomina tę z XIX w. Por. np.: R. Kagan, Powrót historii i koniec marzeń, tłum. G. Sałuda, Poznań 2009.

12 J. Heine, On the Manner of Practising the New Diplomacy, Waterloo 2006, s. 4, http://www. cigionline.org/sites/default/files/paper11_jorge_heine.pdf (dostęp: 31 X 2014).

${ }^{13}$ Ibidem, s. 4-5.

${ }^{14}$ Takich jak: MKOl, FIFA, Union of European Football Associations (Unia Europejskich Związków Piłkarskich; UEFA), International Association of Athletics Federations (Międzynarodowe Stowarzyszenie Federacji Lekkoatletycznych; IAAF) lub Fédération Internationale de Ski (Międzynarodowa Federacja Narciarska; FIS).

${ }_{15}$ Przykładowo Organizacja Narodów Zjednoczonych (ONZ).

${ }^{16}$ Stowarzyszenia na rzecz ochrony środowiska i dziedzictwa kulturowego, przestrzegania praw człowieka, w tym praw kobiet, dzieci, emigrantów, mniejszości narodowych i innych (MNOs to w większości NGO), ale również podmioty komercyjne: koncerny medialne, firmy spożywcze i odzieżowe, kluby sportowe (FC Barcelona czy Chelsea Londyn to również światowe marki). 
- promocji pokoju i tolerancji na świecie, przestrzegania praw człowieka, ochrony środowiska itp. Współpraca z organizacjami pozarządowymi (NGO), takimi jak Amnesty International, lub międzyrządowymi (IGO), jak UNICEF czy UNESCO odegrała znaczący wpływ na ich ukonstytuowanie. Pewne zachowania sa więc potępiane - rasizm, antysemityzm, homofobia, wzywanie do nienawiści itd. Podczas igrzysk w Berlinie (1936) władze olimpijskie nakazały nazistom usunięcie haseł antysemickich i rasistowskich z przestrzeni publicznej, argumentując swą decyzję tym, że ,jeśli pięciokołowa flaga powiewa nad stadionem, nie znajduje się on w Niemczech, lecz w Olimpii" ${ }^{17}$. Reakcja o zbliżonym charakterze miała miejsce podczas piłkarskiego mundialu w Niemczech (2006), gdy Centrum Szymona Wiesenthala, Anti-Defamation League, politycy i znane osobistości protestowali przeciw ewentualnej wizycie prezydenta Iranu Mahmuda Ahmadineżada (2005-2013) po tym, jak w rozlicznych wypowiedziach zanegował on prawdziwość Holokaustu i wzywał do wymazania Izraela z mapy świata ${ }^{18}$.

O ile NGO reprezentują pozytywną stronę dyplomacji sieciowej, wzrastajaccy udział podmiotów komercyjnych skutkuje postępująca komercjalizacja igrzysk, osłabieniem wartości humanitarystycznych, które przyświecały baronowi Pierre'owi de Coubertinowi - twórcy nowożytnych igrzysk olimpijskich. Decyzje o możliwości zorganizowania zimowych igrzysk olimpijskich (2014), najkosztowniejszych $\mathrm{w}$ historii ${ }^{19}$, oraz piłkarskiego mundialu (2018) w Rosji - w państwie niespełniającym wymogów demokratycznych, prowadzacym działania militarne przeciw sąsiadom - można odczytać jako negacje tych wartości. Przyznaniu organizacji piłkarskich mistrzostw świata Katarowi (2022) towarzyszyły równie trafne, co złośliwe, komentarze sugerujace, iż jedynym kryterium wyboru najprawdopodobniej była zamożność kandydata, niewykluczająca łapówek ${ }^{20}$. Nie wzięto również pod uwagę chociażby faktu, iż panujący tam klimat uniemożliwia uprawianie sportów (temperatura $\mathrm{w}$ czerwcu osiaga ponad $50{ }^{\circ} \mathrm{C}$ ). Organizacje humanitarne alarmowały natomiast o katastrofalnej sytuacji miejscowych robotników, praktycznie stanowiących własność swoich pracodawców ${ }^{21}$.

${ }^{17}$ D. Black, B. Peackock, op. cit., s. 714.

${ }^{18}$ Ahmadineżad, zgłaszający chęć przyjazdu do Niemiec, aby obejrzeć spotkanie irańskiej drużyny piłkarskiej, która zakwalifikowała się do finałów i grała w jednej grupie z Portugalia, Meksykiem i Angola, ostatecznie nie przyjechał. Por. L. Harding, D. Campbell, Iran team face mass protest, http://www.theguardian.com/world/2006/jun/11/worldcup2006. iran (dostęp: 31 X 2014).

19 Por. A. Taylor, Russia is Spending Ludicrous of Money on The Winter Olympics, http:// www.businessinsider.com/sochi-olympics-cost-russia-51-billion-2013-2 (dostęp: 31 X 2014).

${ }^{20}$ Por. Qatar World Cup Controversy. Bribes, slavery, alcohol, http://www.theweek.co.uk/ football/qatar-world-cup/55432/qatar-world-cup-controversy-bribes-slavery-and-alcohol (dostęp: 31 X 2014).

${ }^{21}$ Por. O. Aziz, M. Hussain, Qatar Showcase of Shame, http://www.nytimes.com/2014/01/06/ opinion/qatars-showcase-of-shame.html?_r=0 (dostęp: $31 \mathrm{X} 2014)$. 
Większość organizacji sportowych to wyspecjalizowane, wysoce racjonalne organizacje biurokratyczne ${ }^{22}$. Ich podstawowa funkcja, która stała się niezbędna w związku z narastająca kompleksowością współczesnego sportu, jest nadzór nad kwestiami technicznymi: standaryzacja, koordynacją kalendarza, wieloma, nierzadko złożonymi procesami. ISOs spełniają też dwie istotne funkcje dyplomatyczne. Jak piszą Black i Peackock:

Z jednej strony większość IOS (zaczynając od MKOl-u, lecz można to również rozszerzyć na większość tego typu organizacji) obecnie często deklaruje, że ich biurokratyczne struktury mogą służyć wybitnie dyplomatycznym celom: międzynarodowemu pokojowi i szerzeniu tolerancji poprzez zmagania sportowców (lub inne warianty). Z drugiej strony ISO same w sobie funkcjonują również jako multilateralne organizacje lub areny dla nawiązywania stosunków dyplomatycznych [...]. ISO są zatem zarówno aktorami dyplomatycznymi na własnych prawach, starajacymi się promować kwestie społeczne w świecie sportu, oraz formami dyplomatycznej wymiany pomiędzy krajowymi i międzynarodowymi jednostkami, gdzie generalnie naśladuje się reguły panujace w tradycyjnej dyplomacji klubowej ${ }^{23}$.

Próby poprawy relacji amerykańsko-irańskich za pośrednictwem sportu prowadzono w duchu bliskim dyplomacji tradycyjnej. Istotną rolę odegrały też organizacje i związki sportowe. W artykule staram się uwzględniać obie te perspektywy.

\section{Dialog cywilizacji}

„Odwilż” między Stanami Zjednoczonymi a Islamską Republiką Iranu zapoczątkowało istotne wydarzenie polityczne. $23 \mathrm{~V} 1997$ r. wśród 80\% uprawnionych do głosowania (zaledwie 50\% zagłosowało w poprzednich wyborach, 4 lata wcześniej) 69\% (29,7 mln głosujących) wybrało Mohammada Chatamiego - kandydata reformatorów, byłego ministra ds. kultury i przewodnictwa islamskiego z lat 1982-1992 - na stanowisko prezydenta, podczas gdy jego najpoważniejszy konkurent, popierany przez Chameneiego, kandydat konserwatystów Nategh Nuri zdobył zaledwie $25 \%$ głosów (7 mln wyborców) ${ }^{24}$. Zwolennicy Chatamiego, w większości wywodzący się z islamskiej lewicy, która w ciagu kilkunastu lat stopniowo wycofywała się z pozycji radykalnych i przyjęła stanowisko liberalno-centrystowskie ${ }^{25}$, uwierzyli w możliwość demokratyzacji ustroju. W kontekście polityki zagranicznej Chatami usiłował

${ }^{22}$ Częściowo przeczy to przywoływanej już myśli Jorge Heinego o mniej zhierarchizowanym statusie aktorów dyplomacji sieciowej w porównaniu z tymi uczestniczącym w tradycyjnej dyplomacji klubowej.

${ }^{23}$ D. Black, B. Peackock, op. cit., s. 710.

${ }^{24}$ Por. N.R. Keddie, Wspótczesny Iran. Źródta i konsekwencje rewolucji, tłum. I. Nowicka, Kraków 2007, s. 262-264.

${ }^{25}$ Ibidem, s. 264. 
poprawić relacje z pozostałymi krajami muzułmańskim oraz Zachodem. Dużo uwagi poświęcił Stanom Zjednoczonym. W styczniu 1998 r. w wywiadzie prowadzonym przez Christiane Amanpour dla telewizji CNN wyłożył podstawowe założenia koncepcji, którą nazwał „dialogiem cywilizacji”. Powtórzył je we wrześniu tego samego roku podczas wystapienia przed Zgromadzeniem Ogólnym $\mathrm{ONZ}^{26}$. Po zaprezentowaniu imponującej wiedzy na temat historii USA $^{27}$, której dorobek nie ustępuje - jego zdaniem - osiagnięciom starożytnych cywilizacji Wschodu, Chatami zadeklarował:

W odniesieniu do dialogu cywilizacji mamy zamiar korzystać z osiagnięć i doświadczeń wszystkich cywilizacji, zachodnich i niezachodnich, aby podtrzymywać z nimi kontakt. Im bliżej znajdują się filary i esencja tych dwóch cywilizacji, tym łatwiejszy stanie się dialog. Obecnie, po naszej rewolucji, mamy do czynienia z nową fazą odbudowy cywilizacji. Uważamy, że to czego poszukujemy, Ojcowie Założyciele starali się wprowadzić cztery wieku temu. To jest powodem, dlaczego odczuwamy intelektualne pokrewieństwo z istotą cywilizacji amerykańskiejej.

Jak słusznie zauważa Aleksandra Dzisiów-Szuszczykiewicz, „dialog cywilizacji” powstał w odpowiedzi na „zderzenie cywilizacji” - teorię geopolityczna, sformułowana przez Samuela P. Huntingtona w głośnym artykule dla czasopisma „Foreign Affairs” (1993), którą kontynuował w wydanej w 1996 r. książce. Idea, iż możliwe jest: 1) „Poszukiwanie wspólnych obszarów porozumienia pomiędzy cywilizacjami i w ich obrębie w celu stawienia czoła wspólnym, globalnym wyzwaniom”; 2) „Akceptacja współpracy i poszukiwań odpowiednich mechanizmów zarówno dla promocji wspólnych uniwersalnych wartości, jak i zapobiegania globalnym zagrożeniom”; 3) „Zobowiązanie do stosowania zasad sprawiedliwości, równości, pokoju i solidarności oraz fundamentalnych zasad prawa międzynarodowego i Karty Narodów Zjednoczonych" ${ }^{29}$, rzeczywiście stała w sprzeczności z pesymistycznymi założeniami Huntingtona. Twierdził on bowiem, iż:

to kultura i tożsamość kulturowa, będąca w szerokim pojęciu tożsamością cywilizacji, kształtują wzorce spójności, dezintegracji i konfliktu w świecie, który nastał po zimnej wojnie... Najostrzejsze, najpoważniejsze i najgroźniejsze konflikty nie będą się

${ }^{26}$ Statement by H.E. Mohammad Khatami, President of the Islamic Republic of Iran before the $53^{\text {rd }}$ Session of the United Nations General Assembly, http://www.parstimes.com/history/ khatami_speech_un.html (dostęp: 31 X 2014).

${ }^{27}$ Chatami odnosił się przede wszystkim do nauk purytanów, którzy w jego opinii stworzyli system stanowiący połączenie religijności, umiłowania Boga z afirmacją ludzkiej wolności i godności.

${ }_{28}$ Por. transkrypcję rozmowy: http://edition.cnn.com/WORLD/9801/07/iran/interview.html (dostęp: 31 X 2014).

${ }^{29}$ Por. A. Dzisiów-Szuszczykiewicz, Dialog cywilizacji Mohammada Chatamiego jako wspótczesny model stosunków międzynarodowych - alternatywa dla „Zderzenia Cywilizacji” Samuela Huntingtona, http://www.psz.pl/tekst-7569/Aleksandra-Dzisiow-Dialog-Cywilizacji/ Str-2 (dostęp: 31 X 2014). 
w tym nowym świecie toczyć między klasami społecznymi, biednymi i bogatymi czy innymi grupami zdefiniowanymi w kategoriach ekonomicznych, ale między ludami należącymi do różnych kręgów kulturowych ${ }^{30}$.

Pomimo oficjalnego poparcia ze strony ONZ, która 2001 r. ogłosiła „rokiem dialogu między cywilizacjami”"31, Chatami natrafił na poważne trudności ze strony konserwatystów i Chameneiego. Jako najwyższy przywódca, do którego należał decydujaccy głos w kwestii polityki zagranicznej, nie porzucił on konfrontacyjnego języka wobec USA. W Stanach Zjednoczonych nie brakowało zaś osób sceptycznych wobec zbliżenia z Iranem ${ }^{32}$. W zwiazku z trudnościami $\mathrm{z}$ osiagnięciem porozumienia na poziomie politycznym platformą kontaktów z Zachodem stały się kultura (wbrew Huntingtonowi) i sport. Do Teheranu zaproszono m.in. znakomitych filozofów: Niemca Jürgena Habermasa (2002) i Amerykanina Richarda Rorty'ego (2004) ${ }^{33}$. Zachodnia publiczność bardzo ciepło przyjęła irańskie filmy, np. Smak wiśni (1997) Abbasa Kiarostamiego, Czas pijanych koni (2000) Bahmana Ghobadiego, Krag (2000) Jafara Panahiego czy Kandahar Mohsena Makhmalbafa (2001). W odniesieniu do relacji irańsko-amerykańskich niebagatelne znaczenie odegrał sport - zwłaszcza zapasy i piłka nożna. Zasadne jest mówienie o „dyplomacji zapaśniczej” i „dyplomacji piłkarskiej” w nawiązaniu do słynnej „dyplomacji pingpongowej” z wczesnych lat siedemdziesiątych, która ułatwiła nawiązanie stosunków między USA a Chińską Republiką Ludową ${ }^{34}$, czy „dyplomacji krykietowej” umożliwiającej

${ }^{30}$ S.P. Huntington, Zderzenie cywilizacji i nowy kształt ładu światowego, tłum. H. Jankowska, Warszawa 2006, s. 14, 20. Ervand Abrahamian zauważa, iż tezy Huntingtona zawarte w jego wcześniejszej książce Political Order in Changing Societies (1968) stanowić mogły źródło inspiracji dla polityki dynastii Pahlawi. Twierdził w niej m.in., że wyłącznie system jednopartyjny może zapobiec destabilizacji politycznej w rozwijajacych się krajach Trzeciego Świata: ,jedyna partia będzie odgrywać rolę naturalnego łącznika reżimu z krajem, mobilizować społeczeństwo, przekazywać idące z góry na dół nakazy i równocześnie przekazywać w górę interesy dołów społecznych". Por. E. Abrahamian, op. cit., s. 198.

${ }^{31}$ Por. Resolution Adopted By The General Assembly 53/22. United Nations Year of Dialogue Among Civilizations, http://www.un.org/documents/r53-22.pdf (dostęp: 31 X 2014).

${ }^{32}$ Elaine Sciolino z „New York Timesa” ostrzegała: „Chatami jest uroczy, na tyle, iż kuszące jest myślenie o nim jako o demokracie w Jeffersoniańskim stylu przebranym za kleryka. Lecz to nie jest przebranie. On jest jednym z nich”. Zastrzeżenia wobec ewentualnego złagodzenia polityki względem Iranu zgłaszali m.in. Zbigniew Brzeziński i Brent Scowcroft, przeciwna była również większość polityków opozycyjnej względem administracji Clintona Partii Republikańskiej. Por. D. Murray, US Foreign Policy and Iran. American-Iranian Relations since the Islamic Revolution, London-New York 2009, s. 104-105; E. Sciolino, Persian Mirrors. The Elusive Face of Iran, New York 2001, s. 81.

${ }^{33}$ Jeden z czołowych irańskich intelektualistów, obecnie dysydent, Ramin Dżahanbeglu wspomina, iż wizyty Habermasa i Rorty'ego miały ożywczy stosunek dla środowiska intelektualnego. Obydwaj byli czczeni niczym gwiazdy Bollywoodu. Por. http://www.logosjournal. com/issue_5.2/jahanbegloo_interview.htm (dostęp: 31 X 2014).

${ }^{34}$ Por. m.in.: N. Griffin, The Ping-Pong Diplomacy. The Secret History Behind the Game that Changed the World, New York 2014. 
złagodzenie napięcia między Indiami i Pakistanem, zapoczątkowanej w 1987 r., gdy pakistański prezydent Muhammad Zia ul-Haq (1978-1988) oglądał na żywo mecz pomiędzy obiema reprezentacjami ${ }^{35}$.

\section{„Dyplomacja zapaśnicza”}

Przełomem okazał się gościnny udział zapaśników amerykańskich w lutym 1998 r. na zawodach Takhi Cup w Teheranie. Była to pierwsza oficjalna wizyta obywateli USA w Iranie od czasu rewolucji islamskiej i okupacji ambasady amerykańskiej. Wiązała się z rozgrywanymi w Teheranie zawodami na cześć zmarłego w 1968 r. złotego medalisty olimpijskiego z Melbourne (1956), Gholama Rezy Tachtiego. Na trwale wpisały się one w kalendarz sportowy. Udział w zawodach, które dla wielu Irańczyków stanowiły święto, wiązał się $\mathrm{z}$ wieloma obawami podzielanymi przez obydwie strony. Amerykanie nie byli pewni odbioru ze strony publiczności, natomiast w Iranie pojawiły się liczne głosy, najczęściej wyrażane przez konserwatystów, iż ewentualne zwycięstwo Stanów Zjednoczonych i konieczność spoglądania na flagę amerykańska powiewająca nad irańską przyniosłoby hańbę całemu narodowi ${ }^{36}$.

Obawy te okazały się nietrafione. Kibice zgromadzeni w Hali Azadi entuzjastycznie przywitali amerykańskich zawodników - Kevina Jacksona, Melvina Douglasa i Larry'ego „Zeke” Jonesa. Z jednakowa intensywnościa kibicowali oni gospodarzom oraz gościom ${ }^{37}$. Douglas po wyrównanej walce ( $3: 3 \mathrm{w}$ regulaminowym czasie) przegrał z reprezentantem gospodarzy Abbasem Dżadidim. Wymiana uścisków, wspólne uniesienie dłoni w geście zwycięstwa i ceremonia honorowa, w trakcie której Dżadidi obdarowany został portretem Chomejniego, a Douglas - urzędującego wówczas Chameneiego, przełamały pierwsze lody. Gdy Douglas, poinstruowany przez Dżadidiego, z szacunkiem

${ }_{35}$ Śladami swego poprzednika podążył prezydent Pervez Musharraf (2001-2008). W 2005 r. udał się do Indii na mecz krykieta. W 2011 r. na mistrzostwach świata w Indiach, Sri Lance i Bangladeszu obydwie drużyny awansowały do półfinału. Premier Indii Manmohan Singh zaprosił swojego pakistańskiego odpowiednika Yousafa Razę Gillaniego na mecz półfinałowy, który wygrali - podobnie jak cały turniej - współgospodarze. Gillani przyjął to zaproszenie.

${ }^{36}$ Por. K. Naji, Ahmadinejad. The Secret History of Iran's Radical Leader, Berkeley-Los Angeles 2008, s. 187.

${ }^{37}$ Odpowiadało to ogólnym wytycznym mówiącym o jednakowym traktowaniu rywalizujących stron i wystrzeganiu się faworyzowania jednych kosztem drugich. W Iranie nierzadko zdarzają się również sytuacje przeciwne - Gerhardt pisze np. o meczach teherańskich drużyn: Esteghlalu (,Niepodległość”) i Persepolis/ Piruzi (,Zwycięstwo”), gdzie antagonizm pomiędzy kibicami obydwu drużyn można porównać do tego, jaki panuje między zwolennikami Interu Mediolan i AC Milan (tudzież Interu i Juventusu Turyn) lub Realu Madryt i FC Barcelony. Por. M. Gerhardt, Sport and Civil Society in Iran, w: Twenty Years of Islamic Revolution. Political and Social Transition in Iran since 1979, ed. E. Hooglund, New York 2002, s. 43. 
uniósł do góry otrzymany portret, publiczność zareagowała z euforia ${ }^{38}$. Kevin Jackson, złoty medalista z Barcelony (1992), został zaś pierwszym w historii zawodnikiem ze Stanów Zjednoczonych, który zwyciężył w Takhi Cup. Wbrew zapowiedzi konserwatystów widownia wyraziła wielką sympatię do zwycięzcy, skandując jego nazwisko i wymachujacc plastikowymi flagami.

Nie było to ostatnie spotkanie między amerykańskimi a irańskimi zapaśnikami. We wrześniu tego samego roku inne drużyny rywalizowały ze sobą na mistrzostwach świata w stylu wolnym, rozgrywanych również w Teheranie. Iran zwyciężył wówczas w klasyfikacji drużynowej, USA zajęły trzecie miejsce $^{39}$. Areną mistrzostw świata Teheran stał się ponownie w $2002 \mathrm{r}$. W 1996, 2009 i 2013 odbywały się tam coroczne zawody Pucharu Świata w zapasach w stylu wolnym, zaś w 1997, 2005, 2013 i 2014 - w stylu klasycznym ${ }^{40}$. W 2012 r. amerykańska, irańska i pozostałe federacje zapaśnicze (m.in. rosyjska i kubańska) zawiązały sojusz w proteście przeciwko deklarowanym przez MKOl planom zniesienia zapasów jako dyscypliny olimpijskiej po igrzyskach w 2020 r. Zgodna i zdecydowana postawa działaczy stała w opozycji do oficjalnych stosunków między tymi państwami. Rozmowy między USA a Iranem w sprawie irańskiego programu nuklearnego utknęły w martwym punkcie; od czasu rosyjskiej agresji na Gruzję w 2008 r. stosunki między Stanami Zjednoczonymi a Rosja były napięte - sytuacji tej nie zmieniła polityka „resetu” na początku prezydentury Baracka Obamy, która zreszta okazała się krótkotrwała. W mediach kolejny raz po 1998 r. pojawiały się komentarze o „dyplomacji zapaśniczej” ${ }^{41}$. Wspólne i zdecydowane stanowisko Irańczyków, Amerykanów i Rosjan spowodowało, iż zapasy mają zapewniona obecność w programie letnich igrzysk olimpijskich do $2024 \mathrm{r}$.

Zapaśnicy Iranu i Stanów Zjednoczonych nie spotykają się wyłącznie na oficjalnych zawodach. Od 1998 r. amerykańska i irańska federacja zapaśnicza zorganizowała szereg turniejów towarzyskich. W przeciwieństwie do olimpiady, mistrzostw świata czy Pucharu Świata, w których uczestnictwo jest wiążące, a rola gospodarza wyłaniana przez niezależne władze Fédération Internationale des Luttes Associées (Międzynarodowa Federacja Zapaśnicza; FILA), organizacja takich imprez zostaje ustalona $\mathrm{w}$ drodze negocjacji między związkami. Ich częstotliwość i przyjazna atmosfera świadczą o porozumieniu i dobrej woli między zawodnikami i działaczami. Już w lutym 1998 r.,

${ }^{38}$ Zob. drugą część dokumentu BBC, pt. Iran \& The West, wyemitowanego na 30. rocznicę rewolucji islamskiej (2009), http://www.bbc.co.uk/programmes/b00ht3p7 (dostęp: 31 X 2014).

39 Por. http://en.wikipedia.org/wiki/1998_World_Wrestling_Championships (dostęp: 31 X 2014).

${ }^{40}$ W 2006 r. organizatorem Pucharu Świata w stylu wolnym było irańskie Sari nad Morzem Kaspijskim. Por. http://en.wikipedia.org/wiki/FILA_Wrestling_World_Cup (dostęp: 31 X 2014). W większości imprez rozgrywanych w Teheranie zwyciężali gospodarze.

${ }^{41}$ Por. m.in.: H. Morris, Remember Ping-Pong Diplomacy? What about Wrestling Diplomacy?, http://rendezvous.blogs.nytimes.com/2013/02/13/remember-ping-pong-diplomacy-what-about-wrestling-diplomacy/ (dostęp: 31 X 2014). 
w odpowiedzi na ciepłe przyjęcie w Teheranie, amerykańscy działacze wystosowali zaproszenie na przyszłoroczne zawody w USA. Irańczycy z niego skorzystali. W 2013 r. odbył się kolejny mityng w nowojorskim Grand Central Terminal, zatytułowany The Rumble on the Rails (Grzmoty na torach; GCT to monumentalny dworzec kolejowy), w którym Irańczycy pokonali Amerykanów $6: 1$. Wydarzenie to miało istotne znaczenie dla społeczności irańskiej w $\mathrm{USA}^{42}$. W podobnych wymianach uczestniczą m.in. siatkarze, piłkarze czy waterpolowcy. Nie odbywają się one bez zgrzytów organizacyjnych ${ }^{43}$ czy trudniejszych okresów ${ }^{44}$, potwierdzaja jednak tezę, iż sport bywa skutecznym narzędziem dyplomacji i alternatywą dla polityki. Rację ma więc prezes amerykańskiego związku zapaśniczego James Ravannack, twierdząc: „Sport może uleczyć politykę, jeśli tylko politycy na to pozwolą" ${ }^{45}$.

Bill Clinton przyjał zapaśników i działaczy w Białym Domu 13 III 1998 r. ${ }^{46}$ W swoim przemówieniu podziękował im za reprezentowanie kraju na zawodach w Iranie. Uznał, iż przyczynili się oni do rozpoczęcia nowego rozdziału w relacjach amerykańsko-irańskich - polegającego na dialogu, zaś recepcja ze strony Irańczyków okazała się pozytywna. Odniósł się tym samym do autentycznego entuzjazmu okazywanego Amerykanom przez irańskich kibiców. Na postawione przez prezydenta pytanie: „czy byli dla Was mili [Irańczycy]”, jego goście chórem odpowiedzieli, że „byli cudowni”. Entuzjastyczne opinie o kraju i jego mieszkańcach powtarzali także uczestnicy późniejszych wizyt w Iranie ${ }^{47}$.

${ }^{42}$ Por. Iran and U.S. wrestling teams meet in NYC, http://www.cbsnews.com/news/iran-andus-wrestling-teams-meet-in-nyc/ (dostęp: 31 X 2014).

${ }^{43}$ Po wygranej w Nowym Jorku Irańczycy przedwcześnie przerwali swoją wizytę w Stanach Zjednoczonych i nie wzięli udziału w drugich zawodach, które miały się odbyć w Los Angeles. Por. D. Wharton, Iran's wrestling team abruptly decides to skip L.A competition, http://articles.latimes.com/2013/may/17/sports/la-sp-us-iran-wrestling-20130518 (dostęp: 31 X 2014).

${ }^{44}$ W latach 2009-2013, podczas drugiej kadencji Ahmadineżada i fiaska w rozmowach na temat irańskiego atomu, wstrzymano większość wizyt sportowców i wymian między prywatnymi osobami.

${ }_{45}$ Por. B. Slavin, American athletes get star treatment in Iran, http://www.al-monitor.com/ pulse/originals/2014/07/us-athletes-diplomacy-iran.html (dostęp: 31 X 2014).

${ }^{46}$ Film z tej wizyty: https://www.youtube.com/watch?v=A2YKLHXnSp8 [oficjalny kanał William J. Clinton Presidential Library and Museum w Little Rock w serwisie YouTube] (dostęp: 31 X 2014).

${ }^{47}$ Robby Smith, uczestnik mistrzostw świata w Teheranie w 2014 r..., wspomina, iż aplauz ze strony irańskich kibiców był „najbardziej niesamowitym, z jakim kiedykolwiek się spotkał”. Przytacza anegdotę o tym, jak w przerwie pojedynku z zawodnikiem rosyjskim usłyszał rytmiczne bębnienie wśród publiczności i - mimochodem - zaczął uderzać w klatkę piersiową w rytm bębnów. „Przegrywałem $3: 0$. Ludzie spostrzegli co robię i wprost oszaleli - mówi Smith - Zacząłem punktować. Powaliłem go [Rosjanina] w dół i było już $3: 2$. Wypchnałem go z koła i było $3: 3$. W końcu go pokonałem, a cała hala esplodowała. To było szaleństwo [...] Czułem się jak jeden z Beatlesów”. Por. B. Slavin, American ahletes... 
Na spotkaniu w Białym Domu obecny był John D. Marks, przewodniczący założonej w 1982 r. organizacji pozarządowej Search for Common Ground (Szukając Wspólnego Gruntu; SFCG) ${ }^{48}$, zajmującej się poszukiwaniem porozumienia między obywatelami zwaśnionych narodów bądź społeczności za pośrednictwem m.in. spotkań pomiędzy czołowymi osobistościami niebędącymi członkami władz, wymian dwustronnych, kursów, szkoleń, stypendiów itp. Pierwotnym założeniem jej twórców było zbliżenie do siebie społeczeństwa amerykańskiego i radzieckiego. Po 1989 r. głównym obszarem działalności stał się Bliski Wschód, w tym Iran ${ }^{49}$. Od 1996 r. SFCG udało się zaaranżować m.in. szereg wymian między duchownymi szyickimi a chrześcijańskimi celem podkreślenia podobieństw między chrześcijaństwem i islamem ${ }^{50}$. Organizacja pośredniczy również $\mathrm{w}$ wymianach między amerykańskimi a irańskimi studentami oraz przedstawicielami różnych grup zawodowych: naukowcami, lekarzami, duchownymi czy teologami. Wizycie amerykańskich zapaśników w 2014 r. w Teheranie towarzyszył Bahman Bakhtiari, przewodniczacy The International Foundation for Civil Society (Międzynarodowa Fundacja na rzecz Społeczeństwa Obywatelskiego; IFCS) z siedzibą w Salt Lake City. Swoją działalność opiera ona na uznaniu, iż „rozległe zmiany o charakterze politycznym, ekonomicznym i społecznym, które odbywaja się na Bliskim Wschodzie i Ameryce Północnej są odzwierciedleniem potrzeb młodego pokolenia domagającego się poprawy warunków ich życia po dekadach autorytaryzmu" ${ }^{51}$. IFCS podejmuje szereg działań zmierzajacych przede wszystkim do rozwoju społeczeństwa obywatelskiego. Sportowcy i działacze, organizacje takie jak SFCG, IFCS oraz wiele innych spełniają ideę „dialogu cywilizacji” sformułowana przez Chatamiego. Czynią to w stopniu większym niż moga i/lub chca politycy.

\section{„Dyplomacja piłkarska”}

Wydarzeniem o podobnej randze, co pierwsza wizyta zapaśników amerykańskich w Teheranie, stał się mecz piłkarski między reprezentacjami Iranu i Stanów Zjednoczonych w ramach fazy grupowej mistrzostw świata we Francji - 21 VI 1998 r. na Stade de Gerland w Lyonie. Tak samo jak w przypadku udziału Amerykanów na zawodach Takhi Cup, mecz ten wzbudził niepokoje, które również okazały się nieuzasadnione. Władze FIFA nadały mu najwyższy priorytet: zaostrzono środki bezpieczeństwa z obawy

\footnotetext{
${ }^{48}$ Por. https://www.sfcg.org/ (dostęp: 31 X 2014).

${ }^{49}$ Por. https://www.sfcg.org/us-iran-program/ (dostęp: $31 \mathrm{X} 2014$ ).

${ }_{50}$ Por. B. Slavin, Iran extends welcome to US religious groups, http://www.al-monitor.com/ pulse/originals/2014/06/iran-welcome-us-religious-groups.html (dostęp: $31 \mathrm{X} 2014$ ).

${ }^{51}$ Por. http://foundationforcivilsociety.org/about.php (dostęp: 31 X 2014).
} 
przed zamieszkami, jakie spowodować mogli członkowie skonfliktowanej z irańskimi władzami paramilitarnej Organizacji Bojowników Ludowych Iranu (OBL), którzy w swoich działaniach stosowali również terroryzm. Stanowili oni widoczną część widowni (7 tys. spośród 42 tys. osób) na meczu. W transmisji telewizyjnej starano się ignorować ich obecność, jednak udało im się dobitnie zaznaczyć swój sprzeciw wobec teokratycznych władz irańskich, wnosząc banery z hasłem „precz z Chatamim” lub portretami Maryam Rajavi, przewodniczacej National Council of Resistance of Iran (Narodowa Rada Irańskiego Ruchu Oporu), liderki irańskiej opozycji na emigracji ${ }^{52}$. Jednocześnie celem zachęcenia reprezentantów obu zwaśnionych narodów do zachowania zgodnego z duchem gry FIFA ogłosiła 21 czerwca dniem fair play. Mehrdad Masoudi, jeden z koordynatorów tego meczu, wspomina, iż konieczna stała się zmiana protokołu: drużyna Iranu została wylosowana jako gość, co zobowiązuje do wyjścia naprzeciw stojących piłkarzy amerykańskich w celu wymiany uścisków dłoni. Ajatollah Chamenei zakazał im tego czynić i to Amerykanie wyszli naprzeciw Irańczykom, chociaż oficjalnie to oni byli gospodarzami ${ }^{53}$.

Ceremonia powitania na meczu Iran-USA, jedna z najdłuższych w historii mundialu, znacząco różniła się od wszystkiego, co odbyło się do tej pory. Irańczycy obdarowali Amerykanów bukietami białych róż (symbol pokoju). Zamiast osobnych zdjęć piłkarze pozowali do wspólnej fotografii. W uznaniu za swą postawę obydwie drużyny zostały uhonorowane nagrodą FIFA fair play 1 II $1999 \mathrm{r} .{ }^{54}$ Byli oni świadomi politycznej wagi tego meczu, podkreślali jednak pilna potrzebę zwycięstwa $\mathrm{w}$ związku ze wcześniejszymi porażkami w pierwszych meczach fazy grupowej ${ }^{55}$. Irańczycy pokonali Amerykanów $2: 1(1: 0)$ po bramkach Hamida Rezy Estilego w 14 minucie oraz Mehdi Mahdawikii - w 84. Na trzy minuty przed końcem regulaminowego czasu gry kontaktową bramkę zdobył Brian McBride. Amerykanie nie zdążyli już jednak wyrównać. Było to pierwsze zwycięstwo Iranu w drugim dotychczasowym występie na piłkarskich mistrzostwach świata. Irańczycy uczestniczyli na mundialu w Argentynie w 1978 r., w późniejszych latach zakwalifikowali

${ }^{52}$ Por. N. Billingham, 98: the most politically charged game in World Cup history, http:// www.fourfourtwo.com/features/98-most-politically-charged-game-world-cup-history (dostęp: 31 X 2014). Gerhardt pisze, iż część dziennikarzy stwierdziła po meczu, że miał on jednego zwycięzcę: irańską opozycję na emigracji. Stwierdza jednak, że protesty te niewiele wniosły do rozwoju społeczeństwa obywatelskiego w Iranie. Ponadto nie zostały one w odpowiedni sposób dostrzeżone w związku z manipulacją w transmisji przez telewizję publiczna w Iranie. Nie ustrzegły się jej również media zachodnie, nie pokazywano bowiem pewnych wydarzeń uznanych za kłopotliwe, np. zamieszek imigrantów towarzyszących mundialowi. Por. M. Gerhardt, op. cit., s. 44-45, 53-54.

${ }^{53}$ N. Billingham, op. cit.

${ }^{54}$ Por. H.E. Chehabi, The Politics of Football in Iran, w: Fringe Nations in World Soccer, ed. K. Bandyopadhyay, S. Mallick, London-New York 2013, s. 94.

${ }^{55}$ Por. http://en.wikipedia.org/wiki/1998_FIFA_World_Cup\#Group_F (dostęp: 31 X 2014). 
się na mundial w Niemczech (2006) i RPA (2010). Zarówno Amerykanie, jak i Irańczycy ostatecznie nie wyszli z grupy, zostali bowiem wypunktowani przez faworyzowanych Niemców i Jugosłowian.

Pokonanie drużyny ze Stanów Zjednoczonych uznawane jest za największy sukces irańskiej piłki nożnej, stawiany wyżej niż trzy zwycięstwa w Pucharze Azji $(1968,1972,1976)$ czy cztery złote medale na igrzyskach azjatyckich (1974, 1990, 1998, 2002). „Wieczorem 21 czerwca radość wśród irańskich kibiców była więc olbrzymia, jednak - jak zauważają Gilles Amado i Rachel Amato - praktycznie nikt nie wspominał o zwycięzcach i przegranych" 56 . Piłkarze z obydwu drużyn z szacunkiem wypowiadali się o grze przeciwnika. Obrońca USA Jeff Agoos podkreślił polityczną doniosłość tego meczu: „Przez 90 minut zrobiliśmy więcej niż politycy przez 20 lat”" ${ }^{57}$. Jego symboliczna wartość pomogła Amerykanom osłodzić gorycz porażki. Ty Duffy uważa jednak, iż słaby występ na mundialu we Francji paradoksalnie stanowił podstawę pod budowę mocniejszej drużyny ${ }^{58}$. W ostatnich latach piłka nożna stała się coraz bardziej popularna w tym kraju. Dość uzasadnione wydaje się zatem stwierdzenie, iż gdyby spotkanie USA-Iran odbyło się w obecnych czasach, spowodowałoby jeszcze większe zainteresowanie niż w 1998 r., zwłaszcza wśród Amerykanów. Amerykanie i Irańczycy spotkali się ponownie, tym razem na meczu towarzyskim rozgrywanym na stadionie Rose Bowl w Pasadenie w 2000 r. Tym razem mecz zakończył się remisem 1: 1 i przebiegał w „piknikowej” atmosferze.

Meczowi USA-Iran na piłkarskich mistrzostwach świata towarzyszyły wypowiedzi przedstawicieli władz obydwu krajów. Bill Clinton nagrał krótkie przemówienie wyemitowane przed rozpoczęciem spotkania - oficjalnie z okazji Dnia Ojca, który w Ameryce przypadał akurat w tym czasie, co mecz:

Piłkarski Puchar Świata, dlatego jest uwielbiany na całej planecie - stwierdzał - gdyż jest szansa dla ludzi z całego świata, by zostali ocenieni nie z powodu miejsca, w którym dorastali, koloru ich skóry czy wybranej religii, lecz poprzez siłę ich ducha, wytrzymałość, posiadane umiejętności. Mam nadzieję, że mecz ten okaże się krokiem naprzód w kierunku zakończenia alienacji pomiędzy naszymi narodami. Cieszę się, że w ciagu ostatniego roku prezydent Chatami i ja wspólnie pracowaliśmy na tym, aby zachęcić większą liczbę ludzi do bezpośrednich wymian i pomóc naszym obywatelom, by mogli oni w pełni dostrzec wzajemne bogactwa naszych cywilizacji ${ }^{59}$.

${ }^{56}$ G. Amado, R. Amato, Some Distinctive Characteristics of Transitional Change, w: The Transitional Approach to Change, ed. G. Amado, A. Ambrose, London 2001, s. 108.

${ }^{57}$ N. Billingham, op. cit.

58 T. Duffy, The 1998 World Cup And The Making of Modern American Soccer, http://thebiglead.com/2014/05/16/the-1998-world-cup-and-the-making-of-modern-american-soccer/ (dostęp: 31 X 2014).

${ }^{59}$ Por. http://www.usembassy-israel.org.il/publish/press/whouse/archive/1998/june/wh3622. htm (dostęp: 31 X 2014). 
Kilka dni przed rozpoczęciem meczu w podobnym duchu wypowiedziała się ówczesna sekretarz stanu Madeleine Albright. Podczas wystapienia na Forum Azjatyckim w Nowym Jorku akcentowała podobieństwa cywilizacji irańskiej i amerykańskiej, wyraziła też nadzieję na szybkie wprowadzenie „mapy drogowej” prowadzącej do normalizacji wzajemnych relacji ${ }^{60}$.

Jak wspomniano, mecz zakończył się zwycięstwem Iranu. Jego przebieg i rezultat w odmienny sposób skomentowali Chatami i Chamenei. Odzwierciedlili tym samym dzielace ich różnice, które z biegiem czasu okazały się niemożliwe do pogodzenia. Jak zauważa Houchang E. Chehabi, Chatami zwrócił uwagę na istotne walory sprawności sportowej, mogące stanowić jeden ze skuteczniejszych sposobów ukształtowania jedności narodowej, która nie wyklucza wcale tolerancji i respektu dla myślacych inaczej - pod warunkiem uznania wspólnych, akceptowanych przez wszystkich reguł gry. Stanowiło to subtelną aluzję do konfrontacyjnych poczynań obozu konserwatywnego:

\begin{abstract}
To, co liczy się najbardziej to przykładane starania, ciężka praca, pilność, solidarność, wiedza i umiejętności okazywane przez naszą młodzież... - orzekł Chatami - To zwycięstwo to tryumf narodowej jedności wszystkich Irańczyków, niezależnie od politycznych poglądów. Musimy nauczyć się tolerować wzajemnie, niezależnie od dzielących nas różnic i zobowiązać się do rozpoczęcia dyskusji na temat podstawowych reguł gry, to znaczy odpowiednich praw i regulacji... Jeśli uznamy tę zasadę i zgodzimy się stosować ją w szerszym zakresie, to wówczas staniemy się skuteczniejsi przy wypełnianiu naszych codziennych zadań, gdzie zasadniczy akcent pada na umiejętność kolektywnej współpracy - podobnie jak w piłce nożnej, gdzie jedna drużyna występuje przeciw drugiej na gruncie rywalizacji, lecz nie wrogości. Musimy nauczyć się zastosować ten typ myślenia również w odniesieniu do naszego społeczeństwa ${ }^{61}$.
\end{abstract}

Podobnymi motywami kierował się Ali Daei, kapitan reprezentacji Iranu, wybitny snajper (109 goli w 149 meczach międzypaństwowych ${ }^{62}$ ), dedykując zwycięstwo całemu narodowi. Z kolei ajatollah Chamenei wygraną nad Amerykanami postarał się wykorzystać do umocnienia swej antyimperialistycznej - i w gruncie rzeczy antyamerykańskiej - retoryki. Sukces na mundialu porównał do zwycięstwa rewolucji islamskiej i wojny z Irakiem. Mówił o „mądrości, sile, autentycznych i mocno skoordynowanych działaniach mających oparcie w Bogu i że wszystkie te wartości można było zaobserwować na boisku piłkarskim”. Jak stwierdzał:

To były te same nadzwyczajne poczynania, które podczas Rewolucji i Świętej Obrony [wojny iracko-irańskiej w latach 1980-1988 - Sz.P.] oraz we wszystkich

\footnotetext{
${ }^{60}$ Por. G. Amado, R. Amato, op. cit., s. 107.

${ }^{61}$ Cyt. za: ibidem, s. 108.

${ }^{62}$ Por. M. Gerhardt, op. cit., s. 38.
} 
dotychczasowych działaniach powziętych przez irański naród przeciwko Wielkiemu Szatanowi... przyniosły zwycięstwo i honor. Tej nocy, po raz kolejny, silny i arogancki przeciwnik doświadczył goryczy porażki poniesionej z naszych rąk $^{63}$.

\section{Sport a społeczeństwo obywatelskie}

Reakcja większości społeczeństwa odbiegała jednak od przytaczanych stanowisk - umiarkowanego nacjonalizmu Chatamiego i dogmatyzmu Chameneiego. Za prezydentury Chatamiego i jego trudnej „kohabitacji” z najwyższym przywódcą Irańczycy nauczyli się obserwować polityczne potyczki między tymi dwoma stronami z coraz większym dystansem. Chatamiego nazywali „naszym prezydentem”, zaś Chameneiego - „naszym dyktatorem”64. Stopniowo stracili oni wiarę w możliwość głębszych reform, zasadniczą aktywność skupiając na niezależnych mediach, głównie drukowanych, których ilość i jakość radykalnie podskoczyły za rządów Chatamiego. Stały się one najistotniejszym czynnikiem warunkujaccym rozwój krytycznego wobec władzy społeczeństwa obywatelskiego, do czasu aż większość z nich została zamknięta przez skupione wokół Chameneiego stronnictwa konserwatywne.

$\mathrm{Na}$ przeciwległym biegunie kształtowało się nastawienie względem rozgrywek sportowych. Zwłaszcza meczów piłkarskich, po tym, jak piłka nożna ostatecznie zdetronizowała zapasy w wyścigu o miano najpopularniejszej dyscypliny, co nastapiło w latach dziewięćdziesiątych, pomimo faktu, iż to zapaśnicy (oraz ciężarowcy i siatkarze) jako jedyni są w stanie skutecznie rywalizować z zagranica. „Powrót do normalności”, „pierwsza okazja do świętowania od dwudziestu lat”, „Iran zyskał nowy wizerunek” - takie slogany najczęściej wypowiadali po wygranym meczu zgromadzeni na ulicach Irańczycy ${ }^{65}$. Występ reprezentantów ich kraju na piłkarskich mistrzostwach świata - imprezie sportowej o wielkim znaczeniu - stanowił okazję, by porzucić status pariasa, nadany przez społeczność międzynarodową niemal od samego początku funkcjonowania Islamskiej Republiki Iranu. Sukcesy irańskich piłkarzy - występujących w Bundeslidze Alego Daeiego, Alego Karimiego, Khodadada Aziziego czy Mehdiego Mahdawikii, podobnie jak

${ }^{63}$ Cyt. za: S. Peterson, Let the Swords Encircle Me. Iran - a Journey Behind the Headlines, New York 2010, s. 37. Por. też: M. Gerhardt, op. cit., s. 37-39; H.E. Chehabi, The Politics of Football..., s. 94-95.

${ }^{64}$ Por. S. Peterson, On the parquet 'Great Satan' plays for 'Axis of Evil', http://www.csmonitor.com/2005/1215/p01s03-wome.html (dostęp: 31 X 2014). „Wielki Szatan” to określenie, którym irańscy politycy i duchowni określają Stany Zjednoczone, podczas gdy Izrael jest „Małym Szatanem”. W 2002 r. prezydent George W. Bush zaliczył Islamską Republikę Iranu do tzw. osi zła, razem z Irakiem i Koreą Północną. Zlekceważył tym samym pojednawcze gesty okazywane przez Chatamiego po zamachach z 11 IX 2001 r. Poważnie osłabił też pozycję reformatorów w starciu z konserwatystami.

65 Por. G. Amado, R. Amato, op. cit., s. 108. 
reżyserów - Kiarostamiego, Panahiego, Ghobadiego czy Makhmalbafa, podbudowywały narodowe samopoczucie. Okazywało się, że Irańczycy moga być poważani na świecie. Po trwającej kilka dekad zależności kolonialnej od Zachodu (najpierw Brytyjczyków i Rosjan, później Amerykanów) odkrywanie takich faktów miało znaczenie niemalże terapeutyczne.

Marcus Gerhardt w swoim artykule Sport and Civil Society in Iran przedstawia tezę, iż w sporcie, zwłaszcza gdy idzie o sport widowiskowy (spectator sport), często znajduje odzwierciedlenie kondycja danej wspólnoty. W Islamskiej Republice Iranu sport - jako jedna z niewielu dziedzin życia, której władzom nie udało się do końca zmonopolizować - może stanowić podstawę dla funkcjonowania społeczeństwa obywatelskiego, krytycznego względem władzy. Jeden z symptomów upatruje on m.in. w tym, iż przy gwałtownym rozwoju niezależnej prasy za prezydentury Chatamiego zdecydowaną większość stanowiła prasa sportowa ${ }^{66}$.

Chehabi zwraca z kolei uwagę na interesująca zależność między sukcesami irańskiej reprezentacji piłkarskiej a kondycja państwa i samoświadomością społeczeństwa. Awansowi na mundial we Francji (1998) pod koniec listopada $1997 \mathrm{r}$. towarzyszyła nadzieja zwiąana z niedawnym wyborem reformatora Chatamiego na prezydenta Islamskiej Republiki Iranu. Zdaniem Gerhardta publiczna celebracja związana z tym awansem stanowiła „punkt zwrotny w kształtowaniu się irańskiego społeczeństwa obywatelskiego" ${ }^{67}$. Niezakwalifikowanie się reprezentacji na mundial w Korei i Japonii (2002) przepełniło zaś czarę goryczy związanej z rozczarowującym tempem reform, gdy relacje między reformistami a konserwatystami utknęły w martwym punkcie. Tłumy ludzi ponownie wyszły na ulicę, tym razem wyrażając swa frustracje $e^{68}$. Wygrana nad Bahrajnem w czerwcu 2005 r. i awans na mundial w Niemczech (2006) nastapiły w innych okolicznościach politycznych niż 8 lat wcześniej - w tym samym miesiącu urząd prezydenta obją Ahmadineżad, kandydat bliski konserwatystom. Radość z awansu była ogromna. Miała charakter pozapolityczny, aczkolwiek znacząca część społeczeństwa, która uwiódł populistyczny program Ahmadineżada ${ }^{69}$, miała prawo odczuwać, iż zmiany wreszcie zachodzą w pożądanym przez nich kierunku.

Słabą postawę piłkarzy, skutkujaca niezakwalifikowaniem się na mundial w RPA (2010), odczytano jako wierną ilustrację niezadowalającego stanu państwa 30 lat po rewolucji. Jego bezpośrednim i najpoważniejszym skutkiem

${ }_{66}$ Por. M. Gerhardt, op. cit., s. 45.

67 Ibidem, s. 51.

68 Jak podaje Chehabi, jednym z powodów protestów były pogłoski o tym, że konserwatywne władze namawiały piłkarzy, by umyślnie nie awansowali na mundial celem uniknięcia sytuacji, która miała miejsce w 1998 r. Por. H.E. Chehabi, The Politics of Football..., s. 95.

${ }^{69}$ Uboga i antyklerykalna część społeczeństwa, rozczarowana nierównością awansu społecznego po rewolucji, oraz członkowie paramilitarnych organizacji lojalistycznych (pasdaran [Korpus Strażników Rewolucji Islamskiej], basidżowie). Por. N.R. Keddie, op. cit., s. 315-316. 
stał się tzw. zielony ruch ${ }^{70}$, który zawiązał się po tym, jak w wyborach prezydenckich (12 VI 2009) starający się o reelekcję Ahmadineżad zwyciężył, z zastanawiajaca przewaga 63\% do 34\% głosów nad kandydatem obozu reformatorskiego - byłym premierem (1981-1989) Mir-Hosejnem Musawim. Jego przesłanie poparła część piłkarzy ${ }^{71}$. Gdy reprezentacja Iranu ponownie awansowała na turniej w Brazylii (2014), nastały lepsze czasy dla zwolenników reform i liberalizacji - Rada Strażników i ajatollah Chamenei zaakceptowali wybór umiarkowanego duchownego Hasana Rouhaniego. Ich kluczową motywacją była najprawdopodobniej obawa przed powtórzeniem się sytuacji z czerwca 2009 r.

Sport może być zatem efektywnie wykorzystywany jako istotne narzędzie dyplomacji publicznej (public diplomacy), stanowiacej formę pośrednia między dyplomacją tradycyjną a sieciowa. Według definicji opracowanej przez specjalistów z Edward R. Murrow Center for Public Diplomacy (1965) dyplomacja publiczna:

zajmuje się wpływem postaw publicznych na formowanie i egzekwowanie polityki zagranicznej. Obejmuje wymiar stosunków międzynarodowych pozostających poza tradycyjną dyplomacją: kultywowaniem opinii publicznej przez rządy poszczególnych krajów; interakcją prywatnych zbiorowości i grup wpływów w różnych krajach; relacjonowaniem o sprawach międzynarodowych i ich wpływie na politykę; porozumiewaniem się między osobami, których praca jest komunikacja, takich jak dyplomaci i korespondenci zagraniczni, oraz procesami międzykulturowego zbliżenia. Dla dyplomacji publicznej kluczowe znaczenie ma ponadnarodowy przepływ informacji i idei ${ }^{72}$.

Jej znaczenie wzrosło po 11 IX 2001 r. Służy ona pozyskiwaniu informacji dotyczących nastawienia lokalnych władz i społeczności względem USA i amerykańskiej polityki zagranicznej, rzetelnemu informowaniu o jej zasadniczych celach i założeniach odnoszących się do konkretnego państwa bądź terytorium oraz próbom jej legitymizacji wśród autochtonów. Jedna z fundamentalnych wartości dla Amerykanów jest promocja praw człowieka, szczególnie w odniesieniu do reżimów autorytarnych - sprawa ta mieściła się wśród priorytetów administracji Obamy. Ambicją 44 prezydenta USA było ich skuteczniejsze egzekwowanie, np. w porównaniu z podobnymi działaniami podejmowanymi przez administrację Jimmy'ego Cartera (1977-1981), oraz chęć wyraźnego odróżnienia się od dogmatycznej arogancji charakteryzującej prezydenturę George'a W. Busha (2001-2009). Biorac pod uwage jego pozytywne wypowiedzi o przywódcach autorytarnych państw, takich jak Władimir Putin w Rosji, Fatah as-Sisi w Egipcie czy Rodrigo Duterte na Filipinach, można odnieść niedparte wrażenie, iż prawa człowieka raczej nie znajduja się wsród priotytetów obecnego prezydenta Donalda Trumpa.

${ }^{70} \mathrm{O}$,zielonym ruchu” por. m.in.: H. Dabashi, Iran, the Green Movement and the USA. The Fox and the Paradox, London-New York 2010.

${ }^{71}$ Piszę o tym w dalszej części tekstu.

${ }^{72}$ Cyt. za: J.M. Weller, The Public Diplomacy Reader, Washington DC, s. 23. 
W odniesieniu do Islamskiej Republiki Iranu sytuacja jest utrudniona z racji braku oficjalnych kontaktów dyplomatycznych po 1979 r., co skutkuje niedoborem kadry i odpowiedniej infrastruktury. Amerykanie dysponuja jednak pewną liczbą mniej lub bardziej oficjalnych instrumentów umożliwiających w miarę dogodne funkcjonowanie dyplomacji publicznej ${ }^{73}$. Najistotniejsze z nich to Persian News Network (PNN) - stacja radiowa i telewizyjna nadająca audycje w języku perskim oraz Radio Farda (farda w tłumaczeniu z perskiego oznacza ,jutro”) - 24-godzinny kanał radiowy, irański odpowiednik Radia Wolna Europa. Ich głównym zadaniem jest pełnienie funkcji alternatywy wobec kanałów rządowych - przekazywanie wiarygodnych informacji z kraju i ze świata, informowanie o stanowisku Stanów Zjednoczonych, promocja praw człowieka itp. Z racji częstego blokowania ich przekazu przez władze irańskie kolejnym narzędziem stały się media niezależne: prywatna blogosfera oraz media społecznościowe ${ }^{74}$.

Nietypowy charakter relacji amerykańsko-irańskich (a właściwie ich brak) spowodował, iż szczególny nacisk skierowany został na sektor prywatny. Podstawowym celem stała się aktywacja społeczeństwa obywatelskiego. Sport, z racji swego mobilizująco-kontestatorskiego potencjału, bywa wykorzystywany jako dogodny środek do realizacji tego celu. O zasadności dotychczasowych działań świadczy fakt, iż z biegiem lat stopniowo zmienił się ich główny adresat: według danych statystycznych $70 \%$ społeczeństwa irańskiego to ludzie młodzi, poniżej 30. roku życia. Stanowi to efekt inspirowanego przez władze boomu demograficznego w trakcie wojny iracko-irańskiej ${ }^{75}$. Zdecydowana większość z nich nie doświadczyła osobiście rewolucji, okupacji amerykańskiej ambasady lub innych wydarzeń, które uzasadniałyby resentyment czy wręcz nienawiść do Stanów Zjednoczonych. Doskonale pamiętaja za to koncyliacyjna postawę amerykańskich zapaśników w Teheranie i ich życzliwe przyjęcie przez miejscowa publiczność, pojednawczą atmosferę towarzysząca meczowi we Francji, wybuch entuzjazmu po golach Estilego i Mahdawikii. Pozytywne nastawienie do Amerykanów, uwidocznione w lutym 1998 r., przy równoczesnej nieufności wobec amerykańskich władz i prowadzonej przez nie polityki, potwierdzają sondaże $\mathrm{e}^{76}$.

${ }^{73}$ Por. S.M. Riley, Iran and the United Kingdom. A Study in Contrast, w: The Practice of Public Diplomacy. Confronting Challenges Abroad, ed. W.E. Rugh, New York 2011, s. 41-43.

${ }^{74}$ Por. m.in.: http://www.huffingtonpost.com/news/iran-social-media/ (dostęp: 31 X 2014); Liking Facebook in Iran. Social Networking in Iran, Iran Media Program, Center for Communication Studies, Annenberg School for Communication at University of Pennsylvania, Philadephia 2014, http://www.iranmediaresearch.org/en/research/download/1609 (dostęp: 31 X 2014); J. Kelly, B. Etling, Mapping Iran's Public. Politics and Culture in Iran's Blogosfere, Harvard 2008, http://cyber.law.harvard.edu/publications/2008/Mapping_Irans_Online_Public (dostęp: 31 X 2014).

${ }^{75}$ Por. N.R. Keddie, op. cit., s. 281-282; Th. Coville, op. cit., s. 123-125.

${ }^{76}$ Według danych z czerwca 2009 r.: 60\% Irańczyków popiera przywrócenie relacji dyplomatycznych z USA, taki sam procent osób aprobuje rozpoczęcie bezpośrednich rozmów 


\section{Stadion jako fenomen społeczny}

Bastionem wolności i demokratyzacji w Iranie pozostały stadiony (oraz hale, hipodromy i pozostałe obiekty sportowe). W kraju, w którym podział na sferę publiczną i prywatną dość szybko stał się obowiązująca reguła, zrozumiała sama przez siebie i respektowaną (zazwyczaj) przez obydwie strony „umowy” - społeczeństwo i władze - stadion to pewien fenomen społeczny. W sytuacji, gdy przestrzeń publiczna została niemal całkowicie zdominowana przez państwo, a jedynym sposobem obrony przed totalistycznymi zapędami władzy stała się ucieczka w prywatność, którą nierzadko zdarzało się naruszać, np. przez paramilitarne oddziały basidżów strzegących moralności obywateli ${ }^{77}$, stadiony i hale sportowe pozostaja jedynymi fragmentami przestrzeni publicznej niezdominowanej przez władze, gdzie uczestnicy zyskują swobodę zachowań i wypowiedzi praktycznie niespotykana w innych miejscach ${ }^{78}$. Dodatkowym czynnikiem jest swoista „eksterytorialność” aren sportowych, na których odbywają się rozgrywki firmowane logo MKOl, FIFA czy UEFA. Pomimo rozmaitych zabiegów rządzących, usiłujących zmonopolizować areny i rozgrywki sportowe ${ }^{79}$, udało im się zachować dotychczasową autonomię. Stadion w tym kontekście:

jawi się jako fala ciśnieniowa dla napięć i buntów społecznych. To w tym miejscu rozwijają się elementy społeczeństwa obywatelskiego i głosy obywatelskiego protestu, testując granice tolerancji państwa. Jest obszarem, gdzie państwo może łatwo stracić kontrolę, szczególnie jeśli społeczne niezadowolenie przeobrazi się w przemoc. Co istotniejsze, w społeczeństwie, gdzie publiczne i prywatne stały się odrębnymi i oddzielonymi strefami, stadion stanowi sferę publiczna, w której widzowie kontestuja autorytet władz. Należy zaznaczyć, że stadion nie powinien być postrzegany jako miejsce samo w sobie, lecz bardziej jako miejsce symbolizujące widza i środowiska, $\mathrm{w}$ jakie on lub one się angażują ${ }^{80}$.

między obydwoma państwami, 77\% Irańczyków przychyla się do nawiązania normalnych stosunków handlowych, 68\% wyraża nadzieję na owocną współpracę w celu rozwiąania sytuacji w Iraku, 60\% zgadza się na bezwarunkowe negocjacje z Amerykanami - jednak zaledwie $16 \%$ z nich ma nadzieję, iż prezydent Obama będzie w stanie zmienić charakter polityki międzynarodowej, 77\% podziela niechętny stosunek do władz amerykańskich. Por. S.M. Riley, op. cit., s. 38.

77 Por. Th. Coville, op. cit., s. 123-156.

${ }^{78}$ Innym takim miejscem są góry: „[...] otwarte przestrzenie, takie jak góry rozciagające się nad północnym Teheranem, stały się preferowanym miejscem, by wyrazić swój gniew bądź niezgodę - stwierdza Gerhardt - Na wysokich wzgórzach Alborz zarówno jednostki, jak i grupy będące w różnym wieku i reprezentujące różne zawody, mogą połączyć swój zachwyt nad piękną naturą z bezlitosną krytyką reżimu”. Por. M. Gerhardt, op. cit., s. 53.

79 Sprzyjać temu miały m.in. nacjonalizacja klubów piłkarskich, ścisłe związki między właścicielami klubów a politykami, dublowanie się stanowisk w administracji rządowej i związkach sportowych (w latach osiemdziesiątych przewodniczący irańskiego związku zapaśniczego był jednocześnie ministrem obrony).

${ }^{80}$ M. Gerhardt, op. cit., s. 37. 
Rację ma więc przytaczany przez Gerhardta francuski etnolog i iranista Christian Bromberger, pisząc, iż:

Stadiony, które w ciagu ostatnich dziesięciu lat stały się sceną wielu stłumionych demonstracji, pozostaja utrzymywane pod specjalnym nadzorem. Sa przedmiotem strachu władz, w szczególności tych przepojonych purytańskimi wartościami ${ }^{81}$.

Popularność piłki nożnej i pozostałych sportów okazała się problemem dla teokratów po zwycięstwie rewolucji islamskiej. Jak stwierdza Chehabi, nowo ukonstytuowane po 1979 r. władze irańskie powielały w tym zakresie dość ambiwalentne poglądy siedemnastowiecznych brytyjskich purytan, którzy akceptowali sport jedynie wówczas, gdy:

służył racjonalnym przesłankom, to znaczy rekreacji niezbędnej dla utrzymania sprawności fizycznej. Lecz jako środek służący spontanicznej ekspresji pozostających poza wszelką kontrolą impulsów budził podejrzenie i, gdy tylko stał się on wyłącznie oznaką przyjemności, uświadomionej dumy, pierwotnych instynktów lub irracjonalnej potrzeby hazardu, z cała pewnością powinien być zakazany ${ }^{82}$.

Z rozgrywkami sportowymi związane są wydarzenia, które interpretować można jako test na elastyczność rządzących. Awans piłkarzy na mistrzostwa świata we Francji, pierwszy od 1978 r., wywołał eksplozję masowej radości, niemajaca precedensu $\mathrm{w}$ niemal dwudziestoletniej historii reżimu. Trita Parsi wydarzenia z 1998 r. określa mianem „drugiej rewolucji”»3. Tłumy ludzi wybiegły na ulicę, demonstrując entuzjazm z powodu „zwycięskiego” remisu z Australią (2 : $2 \mathrm{w}$ Melbourne dawało awans Irańczykom po wcześniejszym remisie 1:1 w Teheranie), co stało w rażącej sprzeczności z ogólnymi regułami zachowania, które usiłowały (na ogół bezskutecznie) egzekwować władze. $\mathrm{W}$ ich zamyśle dominować powinien nastrój melancholijnego wycofania, wręcz żałoby ${ }^{84}$.

Wspomniana „eksterytorialność” aren objętych opieką organizacji międzynarodowych umożliwia wygłaszanie wypowiedzi bąd́ zaistnienie zachowań nierealnych lub znacząco utrudnionych poza ich obszarem. Takie zdarzenie miało miejsce w Teheranie 17 VI 2009 r. podczas meczu eliminacyjnego do mundialu w RPA między reprezentacjami Iranu i Korei Południowej na Stadionie Azadi. Mecz zakończył się remisem $1: 1$, niwecząc tym samym

${ }^{81}$ Cyt. za: ibidem, s. 41.

${ }^{82}$ Cyt. za: H.E. Chehabi, The Politics of Football..., s. 88.

${ }^{83}$ Por. T. Parsi, Treacherous Alliance. The Secret Dealings of Israel, Iran and the U.S., New Haven 2007, s. 202.

${ }^{84}$ Wywodzące się ze starożytnej tradycji zaratusztriańskiej radosne święto Nowruz (perski Nowy Rok), celebrowane 21 marca, w dzień równonocy wiosennej starano się zastapić dość ponurymi w swej treści obchodami miesiąca Muharram, w trakcie których Irańczycy wspominają męczeńską śmierć imama Husseina poniesioną w bitwie pod Karbalą w 680 r. n.e. 
nadzieje Irańczyków na udział w piłkarskich mistrzostwach świata. Ważniejsza niż jego rezultat okazała się jednak postawa piłkarzy i widzów. Mecz odbył się kilka dni po ogłoszeniu wyników wyborów prezydenckich (12 VI). Kilku piłkarzy, m.in. wybitnie zasłużeni reprezentanci kraju - Mahdawikia (ówczesny kapitan, strzelec drugiego gola w meczu z Amerykanami), Karimi, Hossein Kaebi i Wahid Haszemian - w geście solidarności z tzw. zielonym ruchem - skupionym wokół zwolenników Musawiego protestujących przeciwko domniemanym fałszerstwom wyborczym - występowali z zielonymi opaskami na ręce. $\mathrm{W}$ odpowiedzi władze irańskie zmusiły protestujących piłkarzy do przedwczesnego zakończenia kariery reprezentacyjnej ${ }^{85}$.

W bardziej bezpośredni sposób swój sprzeciw wyrazili kibice. Wielu z nich skandowało antyrządowe hasła i/lub wywiesiło zielone flagi oraz banery z napisami: „Wolny Iran” czy „Precz z Ahmadineżadem”. Na kwestię wykorzystania oficjalnego meczu międzypaństwowego jako platformy protestu, którego zasadnicza treść - żądania demokratyzacji systemu politycznego, podniesienie standardów życia publicznego, przestrzeganie praw człowieka, prawa do godności itp. - pozostaje zgodna z tymi, które (przynajmniej oficjalnie) deklaruje międzynarodowa organizacja piłkarska będąca jego organizatorem, zwracają uwage Brian Kim i Danny Mammo:

Piłkarze i kibice przenieśli polityczne procesy z ulicy na boisko piłkarskie podczas rozgrywek eliminacyjnych FIFA z Koreą Południową. Zamiast opowiedzieć się za władzami, które reprezentuja, piłkarze zdecydowali się założyć zielone opaski na ręce w geście solidarności z Irańczykami protestującym przeciwko działaniom rządu. W ten sposób zarówno piłkarze, jak i kibice spożytkowali międzynarodowy rozgłos towarzyszący meczowi, aby wypromować przesłanie politycznej wolności w Iranie ${ }^{86}$.

Zielone barwy pojawiły się również na innych arenach sportowych, m.in. w Isfahanie i Szirazie ${ }^{87}$. Fakt ten potwierdza istotną funkcję stadionów jako katalizatorów społecznego niezadowolenia, pełnioną niezależnie od deklaracji pomocy i ochrony z zagranicy.

Z perspektywy władz istotnym problemem stał się udział kobiet. Ich obecność na stadionach i halach została zakazana z racji ryzyka wystawienia się na niebezpieczeństwo usłyszenia obraźliwych, wysoce niestosownych słów z ust zgromadzonych tam mężczyzn. Ajatollahowie pośrednio zaakceptowali tym samym spontaniczna, wymykająca się wszelkiej kontroli naturę rozgrywek sportowych. Równocześnie ograniczyli bezpośredni do nich dostęp znaczącej

${ }^{85}$ Por. A Day of Green Silence, http://www.niacinsight.com/2010/01/20/a-day-of-green-silence/ (dostęp: 31 X 2014).

${ }^{86}$ B. Kim, D. Mammo, Iran's Political Corruption and Turmoil. How Football Brought it to Light, http://sites.duke.edu/wcwp/research-projects/middle-east/iran/ (dostęp: 31 X 2014).

${ }^{87}$ Por. http://globalvoicesonline.org/2009/08/21/iran-green-movement-and-football/ (dostęp: 31 X 2014). 
części społeczeństwa ${ }^{88}$. Wyjątek uczyniono dla kobiet pozostałych narodowości, w większości niemuzułmańskich, kibicujących drużynie przeciwnej. W grudniu 1997 r. władze przymknęły jednak oko na obecność kilku tysięcy Iranek podczas uroczystości przywitania piłkarzy na Stadionie Azadi. W tym samym roku utworzona została piłkarska liga kobiet. Rozgrywki odbywaja się w zadaszonych miejscach, do których mężczyźni, w tym trenerzy drużyn, nie mają prawa wstępu ${ }^{89}$.

Częściowe poluzowanie systemu wzbudziło nadzieje na zmiany, które w ostateczności okazały się płonne. Irańskie kobiety do dnia dzisiejszego spotykają się z dyskryminacja, tym boleśniej odczuwaną z racji masowego zainteresowania sportem. Ich sytuację wiernie zobrazował Jafar Panahi w filmie $N a$ spalonym $(2006)^{90}$. W wejściu na stadion nie pomaga też podwójne obywatelstwo. W lecie 2014 r. boleśnie przekonała się o tym Ghoncheh Ghavami, 25-letnia Iranka i obywatelka Wielkiej Brytanii, w której studiuje prawo. Uniemożliwiono jej wejścia na mecz siatkarski między Iranem a Włochami, następnie odesłano do niesławnego więzienia Evin w Teheranie. Sprawą Ghavami zainteresowało się Amnesty International. Pisał o niej m.in. brytyjski „The Guardian” ${ }^{\text {. }}$

Amerykanie wydają się świadomi złożoności sytuacji kobiet w Islamskiej Republice Iranu. W tym kontekście włączenie w skład delegacji amerykańskiej na rozgrywanych w 2014 r. w Teheranie zawodach Pucharu Świata w zapasach stylem klasycznym Christiny „Kiki” Kelley, która pełniła funkcję kierownika drużyny, nabrało szczególnego znaczenia. Kelley, ubrana w „patriotyczny”, czerwono-biało-niebieski turban, pojawiła się na ceremonii otwarcia jako chorąży. Szybko zainteresowały się nią irańskie media zachwycone tym, że choć nie miała takiego obowiązku, postanowiła założyć tradycyjny strój jako wyraz szacunku dla kultury irańskiej. Wraz z resztą drużyny i działaczy przedłużyła swój pobyt w Iranie, wizytując różne miejsca i spotykając się z miejscową ludnością. Z drugiej strony Kelley była pierwszą kobieta, która pojawiła się na wypełnionej po brzegi hali sportowej w trakcie prestiżowych zawodów. Nie miała też wątpliwości, iż w niedługim czasie znajda się jej następczynie:

${ }^{88}$ Kobiety mają prawo do oglądania transmisji telewizyjnych, co na początku funkcjonowania republiki islamskiej nie było wcale oczywistością i do dzisiaj wywołuje sprzeciw niektórych duchownych.

${ }^{89}$ A. Burke, Iran, Melbourne 2010, s. 51.

${ }_{90}$ Por. m.in.: Sz. Pietrzykowski, Rzeczywistość społeczna Islamskiej Republiki Iranu w filmach Jafara Panahiego, w: Obywatele $w$ działaniu. Orient a przemiany społeczne, red. K. Żakowski, M. Stańczyk, Łódź 2012, s. 122-123, http://www.zaw.uni.lodz.pl/ksiazki/ Obywatele_w_dzialaniu.pdf (dostęp: 31 X 2014).

${ }^{91}$ Por. J. Halliday, British-Iranian woman jailed for a year for trying to watch volleyball game, http://www.theguardian.com/uk-news/2014/nov/02/british-iranian-woman-jailed-watchvolleyball-game (dostęp: $31 \mathrm{X} 2014$ ). 
Po ceremonii wszyscy zostaliśmy eskortowani z powrotem do poczekalni - relacjonuje - Wówczas uderzyła mnie historyczna wielkość tej chwili i łzy potoczyły się po mojej twarzy. Mali chłopcy za kulisami okazali mi troskę. Uśmiechnęłam się do nich i starałam się wytłumaczyć, że były to łzy szczęścia. Chłopcy, łamiąc kulturowy protokół, podeszli do mnie, uścisnęli dłonie i jeszcze raz spojrzeli mi w oczy. To wtedy pomyślałam, że gdy ci chłopcy staną się dorosłymi mężczyznami - gdy zostaną zapaśnikami - wszystko będzie inaczej, wszystko ulegnie zmianie. Że pojawi się więcej niż jedna kobieta $\mathrm{w}$ tej hali. I że miałam szczęście być tam w tej chwili, reprezentując kobiety, które z pewnością za mną podążą jako kierowniczki zespołów, trenerki, sędzinie i zapaśniczki ${ }^{92}$.

Manewr z wyborem kobiety jako kierownika drużyny wysłanej do kraju, gdzie dyskryminacyjne ustawodawstwo i zachowania są codziennością, odpowiadał duchowi dyplomacji publicznej. Założenie czadoru stanowiło uprzejmy gest $\mathrm{w}$ kierunku miejscowych. Umożliwiło zdobycie ich sympatii (Kelley nazywano „skromną Amerykanką" ${ }^{33}$ ) i rozpoczęcie dialogu. Jednocześnie symboliczna siła tego wydarzenia - obecności kobiety w hali wypełnionej 5 tys. mężczyzn - wydaje się na tyle znacząca, iż jest ona w stanie uruchomić potencjalne zmiany. Zmiany oczekiwane przez znaczącą część społeczeństwa.

\section{Konkluzje}

Na podstawie relacji amerykańsko-irańskich po 1979 r., w których szczególne miejsce zajmuje rok 1998 jako data ogłoszenia programu „dialogu cywilizacji” i ustanowienie „dyplomacji zapaśniczej” oraz „piłkarskiej”, będące bezpośrednimi rezultatami tego wydarzenia, zasadna wydaje się teza, iż sport, a zwłaszcza sport widowiskowy, w niektórych przypadkach znajduje zastosowanie jako alternatywne narzędzie dyplomacji. Sport może znajdować się w opozycji do polityki i oficjalnej dyplomacji jako jej skuteczniejsza i bardziej bezpośrednia forma (co wynika z przytaczanych wypowiedzi działaczy i sportowców, np. Agoosa czy Ravannacka). Może stanowić jej uzupełnienie. Imprezom i wydarzeniom, takim jak pierwsza wizyta zapaśników amerykańskich w Teheranie czy mecz Iran-USA na piłkarskich mistrzostwach świata, towarzyszyły bowiem komunikaty bądź wystapienia polityków, przez co pośrednio spełniały one funkcję przynależną tradycyjnej dyplomacji klubowej. Ze sportem wiąże się również działalność ISOs i innych podmiotów będących stronami w dyplomacji sieciowej. Sport przyczynia się do rozwoju społeczeństwa obywatelskiego, prowokuje sytuacje nie do pomyślenia (z perspektywy teokratycznych władz irańskich) - odpowiada to roli, którą powinna pełnić

\footnotetext{
${ }_{92}$ B. Seeley, U.S. Men's Olympic Wrestling Team Makes History With Female Team Leader, http://www.huffingtonpost.com/bri-seeley/us-mens-olympic-wrestling-team-makes-history_b_5589576.html (dostęp: 31 X 2014).

${ }_{93}$ Ibidem.
} 
dyplomacja publiczna. W sytuacji, gdy możliwość odczytania rzeczywistych nastrojów społecznych oraz promocji humanitaryzmu i demokracji stała się mocno utrudniona, stadion i pozostałe obiekty sportowe powinny służyć jako pierwszorzędne źródło informacji i główny obszar działania.

Niewykluczone jest jednak, iż zasadnicza funkcja sportu pozostaje zgoła odmienna, np. umacnianie nacjonalizmu, pogłębianie narodowych bądź regionalnych resentymentów. Racje miałby wówczas George Orwell twierdzący, iż „międzynarodowy sport nie jest niczym innym jak wojną bez strzelania” 94 W szczególności wydaje się ona istotna $\mathrm{w}$ odniesieniu do młodych narodów zamieszkujących państwa o niewielkim obszarze. Sport jawi się wówczas jako niepowtarzalna i często jedyna okazja, by skonfrontować się z resztą świata i poprawić wspólnotowe samopoczucie w przypadku ewentualnych zwycięstw. Jak mówi bowiem przywoływany przez Gerhardta wybitny kameruński piłkarz Roger Milla: „To dzięki futbolowi małe państwa mogą stać się wielkie”. Iran nie jest ani młodym narodem (a zasadniej - konglomeratem narodów ${ }^{96}$ ), ani małym państwem. Tradycje Persów sięgaja starożytności. Stanowi to podstawę ich specyficznego poczucia wyższości w porównaniu z innymi narodami, zwykle wobec sztucznie utworzonych emiratów arabskich, zachwianego w następstwie nie tak dawnej zależności kolonialnej od Zachodu. Islamska Republika Iranu zajmuje łącznie powierzchnię $1648195 \mathrm{~km} \mathrm{kw.,} \mathrm{co} \mathrm{sytuuje}$ ją na 18 pozycji wśród największych państw świata97. Wciąż żywa pozostaje pamięć o imperium Achemenidów (550-330 p.n.e.) za panowania Cyrusa II Wielkiego, Dariusza I Wielkiego czy Kserksesa I bądź imperium Sasanidów (224-651 n.e.) $)^{98}$; najpoważniejszym jej przejawem sa wielokrotnie deklarowane aspiracje do odgrywania roli mocarstwa regionalnego. Sportowe zmagania z Amerykanami (lub innymi nacjami) - w większości zwycięskie (irańscy zapaśnicy mają dodatni bilans spotkań z Amerykanami, piłkarze pokonali USA na wielkiej imprezie, podobne sukcesy odnoszą ciężarowcy i siatkarze) - mogą utwierdzać narrację nacjonalistyczną. Starają się to czynić niektórzy politycy - ajatollah Chamenei zwycięski mecz z Amerykanami porównywał przecież do zwycięskiej rewolucji.

Kolejne zastrzeżenie odnosi się do nierównomiernej widoczności (tudziė̇ widowiskowości) współczesnego sportu masowego, w której Black i Peackock

${ }^{94}$ Cyt. za: D. Black, B. Peackock, op. cit., s. 711.

${ }_{95}$ M. Gerhardt, op. cit., s. 49.

${ }^{96}$ Według danych CIA 61\% społeczeństwa stanowią Persowie, 16\% - Azerowie, 10\% - Kurdowie, $6 \%$ - Lurowie, $2 \%$ - Arabowie, $2 \%$ - Beludżowie, $2 \%$ - Turkmeni. Por. https://www. cia.gov/library/publications/the-world-factbook/geos/ir.html (dostęp: $31 \mathrm{X} 2014$ ).

97 Por. http://en.wikipedia.org/wiki/List_of_countries_and_dependencies_by_area (dostęp: 31 X 2014).

${ }^{98}$ Znacząco przyczyniła się do tego faworyzacja przedmuzułmańskiego okresu w historii kraju, praktykowana za panowania dynastii Pahlawi. Dobitnym tego przejawem były wystawne uroczystości z okazji 2500-lecia imperium perskiego obchodzonego w 1971 r. w Persepolis. 
dostrzegają jeden z argumentów za jego wykorzystaniem jako narzędzia dyplomacji. O ile zapasy pozostają irańskim sportem narodowym, a pasję do piłki nożnej Irańczycy dzielą z Europejczykami, o tyle w USA zapasy sa sportem dość niszowym ${ }^{99}$, a futbol (nazywany soccerem) dopiero zyskuje popularność. Drugie, bardziej pozytywne i twórcze oblicze sportu, które przeważa nad pierwszym i znalazło swój wyraz m.in. w przyjaznej atmosferze podczas zawodów Takhi Cup w lutym 1998 r., serdecznym powitaniu między reprezentacjami USA i Iranu na meczu piłkarskim rozgrywanym cztery miesiące później czy udziale Kelley na zapaśniczym Pucharze Świata w Teheranie (2014), może nie zostać przez to odpowiednio dostrzeżone. Należy mieć nadzieję, iż tak się nie stanie.

\section{Streszczenie}

Na przykładzie relacji amerykańsko-irańskich po 1979 r. w artykule przedstawiona jest teza, iż sport bywa wykorzystywany jako nieoficjalne narzędzie dyplomacji. Sport, zwłaszcza współczesny sport masowy angażujący znaczącą liczbę ludzi jako widzów i obserwatorów, pośrednio pełni funkcje przypisane tradycyjnej dyplomacji klubowej (club diplomacy) oraz dyplomacji sieciowej (network diplomacy). W artykule ukazana została charakterystyka obu wspomnianych typów i ich związek ze sportem. Z jednej strony aktywizuje on działania polityków, niebagatelne znaczenie posiadają też konkretne zdarzenia polityczne: zwycięstwo reformatora Mohammada Chatamiego w wyborach prezydenckich w Iranie (1997) i ogłoszenie przez niego koncepcji „dialogu cywilizacji” (1998), co odpowiada pierwszemu z wymienionych typów. Z drugim zaś związane jest funkcjonowanie licznych organizacji o charakterze międzynarodowym (FIFA, MKOl i in.), które również angażują się w działalność dyplomatyczną. W kontekście reżimów autorytarnych, jakim niewątpliwie jest Islamska Republika Iranu (oraz przedrewolucyjny Iran dynastii Pahlawi), sport nierzadko służy aktywizacji społeczeństwa obywatelskiego, a stadion to istotny obszar niezależnej i krytycznej względem władz aktywności obywatelskiej - odgrywa zatem rolę, jaką nominalnie wypełniać ma przez trzeci omawiany tu typ dyplomacji - dyplomacja publiczna (public diplomacy). Zasadnicze miejsce zajmuje analiza dwóch przypadków (case study) - próby wznowienia relacji pomiędzy USA a Islamską Republiką Iranu za pośrednictwem zapasów („dyplomacja zapaśnicza”) oraz piłki nożnej (,dyplomacja piłkarska”). Oba miały miejsce w 1998 r. - niezwykle istotnym dla wzajemnych relacji między obydwoma państwami - który nie przyniósł jednak zasadniczego przełomu.

\section{Sports as alternative instrument of diplomacy on the example of US-Iran relations after 1979}

Using the US-Iran relations after year 1979 as a vital example, the article states that sport is oftentimes used as an unofficial instrument of diplomacy. Sports, especially contemporary mass disciplines involving a significant number of people as spectators, may fulfill functions assigned to traditional club diplomacy and network diplomacy (the characteristics of these both types and their connection to sport is further analysed). One the one hand sport

${ }_{99}$ Dużo popularniejsza od tradycyjnych zapasów jest ich steatralizowana wersja promowana przez amerykańską spółkę prywatną World Wrestling Entertainment. 
activates politicians, on the other hand however it draws inspiration from specific political events - such as the electoral victory of reformist Mohammad Khatami in 1997 and following announcement of his idea of "Dialogue among Civilisations" (1998), which corresponds well with abovementioned club diplomacy. Network diplomacy, in turn, is closely related with the functioning of numerous international organisations (FIFA, IOC, and others) that also engage in various diplomatic activities. In the context of authoritarian regimes, such as the Islamic Republic of Iran (as well as the pre-revolution Iran during the Pahlavi dynasty), sport is often used to promote civil society; the stadium is an important area of independence and civil activity, critical of the regime - and thus it plays the role typically assigned to another, third type of diplomacy, i.e. public diplomacy. Essential part of the paper is devoted to the analysis of two case studies - the so called "wrestling diplomacy" and "football diplomacy" - attempts aimed at restoring the relations between the US and Iran. They both took place in the 1990s but, as it turned out, did not bring about any major breakthrough.

\section{Bibliografia}

Abrahamian E., Historia wspótczesnego Iranu, tłum. N. Nowak, Warszawa 2011.

Amado G., Amato R., Some Distinctive Characteristics of Transitional Change, w: The Transitional Approach to Change, ed. G. Amado, A. Ambrose, London 2001, s. 87-118.

Black D., Peackock B., Sport and Diplomacy, w: The Oxford Handbook of Modern Diplomacy, ed. A.F. Cooper, J. Heine, R. Thakur, Oxford 2013, s. 708-725.

Coville Th., Najnowsza historia Iranu. Republika islamska, tłum. K. Pachniak, Warszawa 2009.

Gerhardt M., Sport and Civil Society in Iran, w: Twenty Years of Islamic Revolution. Political and Social Transition in Iran since 1979, ed. E. Hooglund, New York 2002, s. 36-52.

Heine J., On the Manner of Practising the New Diplomacy, Waterloo 2006.

Chehabi H.E., The Politics of Football in Iran, w: Fringe Nations in World Soccer, ed. K. Bandyopadhyay, S. Mallick, London-New York 2013, s. 77-105.

Keddie N.R., Wspótczesny Iran. Źródła i konsekwencje rewolucji, tłum. I. Nowicka, Kraków 2007.

Riley S.M., Iran and the United Kingdom. A Study in Contrasts, w: The Practice of Public Diplomacy. Confronting Challenges Abroad, ed. W.A. Rugh, New York 2011, s. 37-55.

Stolarczyk M., Iran. Państwo i religia, Warszawa 2001.

Biogram: Szymon Pietrzykowski - absolwent Wydziału Historycznego Uniwersytetu im. Adama Mickiewicza w Poznaniu (2012), od 2013 r. doktorant w Zakładzie Historii Powszechnej XIX i XX w. IH UAM. Obszar zainteresowań: historia powszechna po 1945 r., Holocaust studies, dwudziestowieczne reżimy autorytarne i totalitaryzmy, intelektualiści a polityka, historia Bliskiego Wschodu ze szczególnym uwzględnieniem Islamskiej Republiki Iranu. E-mail:sz.p@onet.eu. 